\title{
Nitrous oxide production and nitrification kinetics by natural bacterial communities of the lower Seine river (France)
}

\author{
Aurélie Cébron $^{1,2}$, Josette Garnier ${ }^{1, *}$, Gilles Billen ${ }^{1}$ \\ ${ }^{1}$ UMR Sisyphe 7619, Université P. et M. Curie - Paris 6, BP 105, Tour 56-55, Étage 4, 4 place Jussieu, 75005 Paris, France \\ ${ }^{2}$ Present address: Department of Biological Sciences, University of Warwick, Coventry CV4 7AL, UK
}

\begin{abstract}
Nitrous oxide $\left(\mathrm{N}_{2} \mathrm{O}\right)$ is produced in the lower Seine river at 40 to $60 \mathrm{~kg} \mathrm{~N}-\mathrm{N}_{2} \mathrm{O} \mathrm{d}{ }^{-1}$, in a section greatly affected by effluents from the Achères Wastewater treatment plant (WWTP). Because water column denitrification is weak in this sector, we hypothesized that $\mathrm{N}_{2} \mathrm{O}$ could be produced by the nitrifier-denitrification process. To understand the controls of $\mathrm{N}_{2} \mathrm{O}$ emission, nitrifying bacterial cultures were grown from Seine river water (in batches and continuous flow experiments). The population diversity of ammonia oxidizing bacteria (AOB) in these experiments was determined by denaturing gradient gel electrophoresis (DGGE) and found to be similar to those naturally present in the Seine. We determined nitrification kinetics of the 2 functional bacteria populations (AOB and nitrite oxidizing bacteria [NOB]). During nitrifying batch and continuous flow experiments, the $\mathrm{N}_{2} \mathrm{O}$ production kinetics were examined under contrasted conditions. We tested the effect of dissolved oxygen, ammonia and nitrite concentrations on the $\mathrm{N}_{2} \mathrm{O}$ production rate. To our knowledge, this is the first study determining the optimal concentrations of $\mathrm{O}_{2}, \mathrm{NH}_{4}{ }^{+}$and $\mathrm{NO}_{2}{ }^{-}$that will lead to maximum $\mathrm{N}_{2} \mathrm{O}$ production by nitrifier-denitrification of mixed nitrifying bacteria populations from natural freshwater. We tested a range of oxygen concentrations and observed a peak in $\mathrm{N}_{2} \mathrm{O}$ emission within the narrow range from 1.1 to $1.5 \mathrm{mg} \mathrm{O}_{2} \mathrm{l}^{-1}$. We plotted the $\mathrm{N}_{2} \mathrm{O}$ production as a function of ammonium and nitrite concentrations under optimal dissolved oxygen conditions. The results followed the hyperbolic Michaëlis-Menten type curves, and kinetics parameters $\left(V_{\max }\right.$ and $\left.K_{s}\right)$ were determined. The maximum $\mathrm{N}_{2} \mathrm{O}$ production rate $\left(V_{\max }\right)$ was estimated at 8 to $9 \mu \mathrm{g} \mathrm{N}-\mathrm{N}_{2} \mathrm{O}$ mg C biomass ${ }^{-1} \mathrm{~h}^{-1}$. The half-

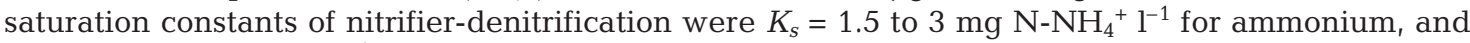
$K_{s}=1$ to $4 \mathrm{mg} \mathrm{N}-\mathrm{NO}_{2}{ }^{-}{ }^{-1}$ for nitrite.
\end{abstract}

KEY WORDS: Nitrous oxide $\cdot$ Nitrification $\cdot$ Nitrifier-denitrification $\cdot$ Continuous flow $\cdot$ Batch cultures

\section{INTRODUCTION}

Nitrous oxide $\left(\mathrm{N}_{2} \mathrm{O}\right)$ is an active greenhouse gas with high environmental impact due to its strong global warming potential (320 times greater than $\mathrm{CO}_{2}$; Wrage et al. 2004). As the atmospheric concentration of $\mathrm{N}_{2} \mathrm{O}$ has increased by $15 \%$ since pre-industrial times, stabilization at the current level of 311 to $313 \mathrm{ppb}$ would require a reduction in anthropogenic emissions of more than $50 \%$ (Houghton et al. 1996). In the stratosphere, $\mathrm{N}_{2} \mathrm{O}$ reacts with oxygen to form nitric oxide (NO), which plays a role in destruction of the ozone layer (Crutzen 1981). $\mathrm{N}_{2} \mathrm{O}$ production by aquatic environments represents $35 \%$ of the total $\mathrm{N}_{2} \mathrm{O}$ emission sources, and the anthropized continental aquatic environments contribute to $10 \%$ of these total emissions (Seitzinger 2000).

Denitrification and chemolithotrophic nitrification appear to be the main biological sources of $\mathrm{N}_{2} \mathrm{O}$ emission. Denitrifying bacteria are involved in the production of gaseous oxidized compounds in environments such as soils, sediment, anoxic waters and sewage sludge. Ammonia oxidation by autotrophic bacteria (ammonia oxidizing bacteria, AOB) can also produce 
$\mathrm{N}_{2} \mathrm{O}$ either as a by-product of aerobic nitrification or through nitrifier-denitrification. As a by-product of nitrification, $\mathrm{N}_{2} \mathrm{O}$ can be formed during the spontaneous decomposition of intermediates in ammonia oxidation (e.g. hydroxylamine, $\mathrm{NH}_{2} \mathrm{OH}$ ), but is essentially issued from nitrifier-denitrification (i.e. ammonia oxidation to nitrite $\mathrm{NO}_{2}^{-}$followed by reduction to molecular nitrogen $\mathrm{N}_{2}$ and $\mathrm{N}_{2} \mathrm{O}$ ) in oxygen-depleted environments (Poth \& Focht 1985, Wrage et al. 2001). Studies describing $\mathrm{N}_{2} \mathrm{O}$ emissions from nitrification are still scarce in natural aquatic environments, but Svensson et al. (2001) demonstrated that nitrification may be the major source of $\mathrm{N}_{2} \mathrm{O}$ in bioturbated lake sediments, and Bonin et al. (2002) and Dong et al. (2002) demonstrated that nitrification can significantly contribute to $\mathrm{N}_{2} \mathrm{O}$ emission in the maximum turbidity zone of estuaries.

Since 1997, we have studied $\mathrm{N}_{2} \mathrm{O}$ emission in the lower Seine river from Paris to the estuary, and an overall $\mathrm{N}_{2} \mathrm{O}$ emission budget has recently been estimated (Garnier et al. in press). This stretch of the river is greatly affected by effluents from the Achères Wastewater Treatment Plant (WWTP) that contribute to oxygen depletion of the water column, first by the activity of heterotrophic bacteria immediately downstream of the effluent discharge, and then by autotrophic nitrification in the estuary (Garnier et al. 2001). Negligible denitrification in the water column (Sébilo et al. in press) and high nitrification (Brion et al. 2000, Garnier et al. 2001, Cébron et al. 2003) provided the justification to focus our research on $\mathrm{N}_{2} \mathrm{O}$ emissions from nitrification.

Nitrifier-denitrification has been investigated since 1972 when Ritchie \& Nicholas (1972) performed isotopic ${ }^{15} \mathrm{~N}$ experiments on pure cultures of AOB Nitrosomonas europaea; Poth \& Focht (1985) also demonstrated this process with $N$. europaea cultures, but only under anoxic stress conditions. Most previous studies have used pure culture strains, including $N$. europaea, N. eutropha or Nitrosospira briensis (Kester et al. 1997, Wrage et al. 2004), and investigations on natural populations are scarce and confined to soils (Hutchinson et al. 1993) or sewage sludge (Muller et al. 1995).

Previous work on the lower Seine river showed that species used for the pure culture studies cited above are not well represented in the natural AOB community, which is instead dominated by Nitrosomonas oligotropha and $N$. ureae-like bacteria belonging to Cluster $6 a$ of $\beta$-Proteobacteria (Cébron et al. 2003, 2004). To our knowledge, information on kinetic parameters and $\mathrm{N}_{2} \mathrm{O}$ production by this bacterial cluster does not exist, and kinetic parameters can vary greatly among bacteria that are phylogenetically similar.

Our objective was to experimentally determine the kinetics of nitrification and nitrifier-denitrification $\mathrm{N}_{2} \mathrm{O}$ production using a mixed bacterial community from the Seine river water, dominated by Nitrosomonas oligotropha- and $N$. ureae-like ammonia oxidizers (Cébron et al. 2004), in order to document the process of nitrifier-denitrification and to determine critical controls and process rates. A second objective was to determine the effect of low oxygen pressure and substrate concentrations (ammonia and nitrite) on $\mathrm{N}_{2} \mathrm{O}$ production by nitrifier-denitrification, which has not been previously studied with mixed freshwater natural populations.

Further, we proposed mathematical functions for the different steps of the nitrification process - e.g. ammonium oxidation, nitrite oxidation and $\mathrm{N}_{2} \mathrm{O}$ emissions in order to provide kinetics formulae and parameter values that could be included in further modelling approaches devoted to simulating the emission of greenhouse gas.

\section{MATERIALS AND METHODS}

Sampling station description. The Seine river is greatly affected by the discharge of effluents from the Achères WWTP, $70 \mathrm{~km}$ downstream from Paris. The WWTP effluents contain high quantities of ammonia (around $30 \mathrm{mg} \mathrm{N}-\mathrm{NH}_{4} \mathrm{l}^{-1}$ ), which is oxidized into nitrite and nitrate in the lower Seine river and the upstream freshwater estuary via the nitrifying process (Brion et al. 2000, Cébron et al. 2003).

Water was collected from the Duclair station, $278 \mathrm{~km}$ downstream from Paris, in the freshwater part of the upstream estuary, where potential nitrification is the highest and is often accompanied by strong oxygen depletion (Brion \& Billen 2000, Garnier et al. 2001, Cébron et al. 2003). Samples were collected at different times throughout 2002 and 2003, but invariably during periods characterised by low water levels (from May to September) when the water temperature was above $17^{\circ} \mathrm{C}$. This water from the Seine freshwater estuary was used for batch and chemostat culture experiments.

Batch culture experiments. Seven different 101 batch cultures of Seine river nitrifying bacterial populations were set up with water from the Duclair station, to which $\mathrm{NH}_{4} \mathrm{Cl}$ was added $\left(30 \mathrm{mg} \mathrm{N}-\mathrm{NH}_{4}{ }^{+} \mathrm{l}^{-1}\right.$, followed by 1 or 2 further additions of $\mathrm{NH}_{4} \mathrm{Cl}$ when ammonium was completely depleted) (Fig. 1a). According to in situ concentrations, initial water composition of $\mathrm{N}-\mathrm{NH}_{4}{ }^{+}$and $\mathrm{N}-\mathrm{NO}_{3}{ }^{-}$varies among batch experiments (from 0.1 to $0.9 \mathrm{mg} \mathrm{N}-\mathrm{NH}_{4}{ }^{+} \mathrm{l}^{-1}$ and from 6.5 to $12.7 \mathrm{mg} \mathrm{N}-\mathrm{NO}_{3}{ }^{-}{ }^{-1}$ ); however, the AOB diversity of the Seine river was similar throughout low water conditions (Cébron et al. 2004). The cultures were run for 2 to $3 \mathrm{wk}$ under constant shaking. Constant dissolved oxygen concentra- 
a

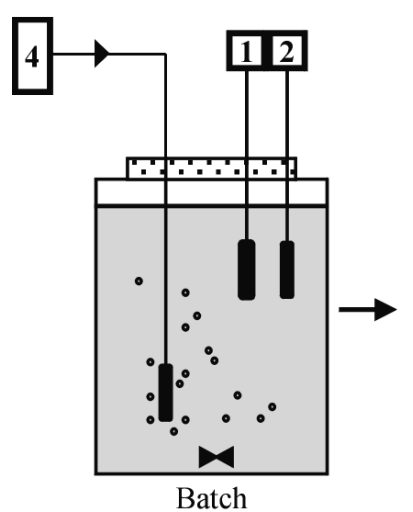

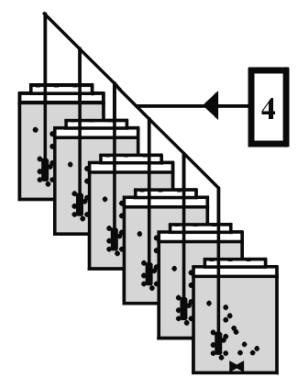

b

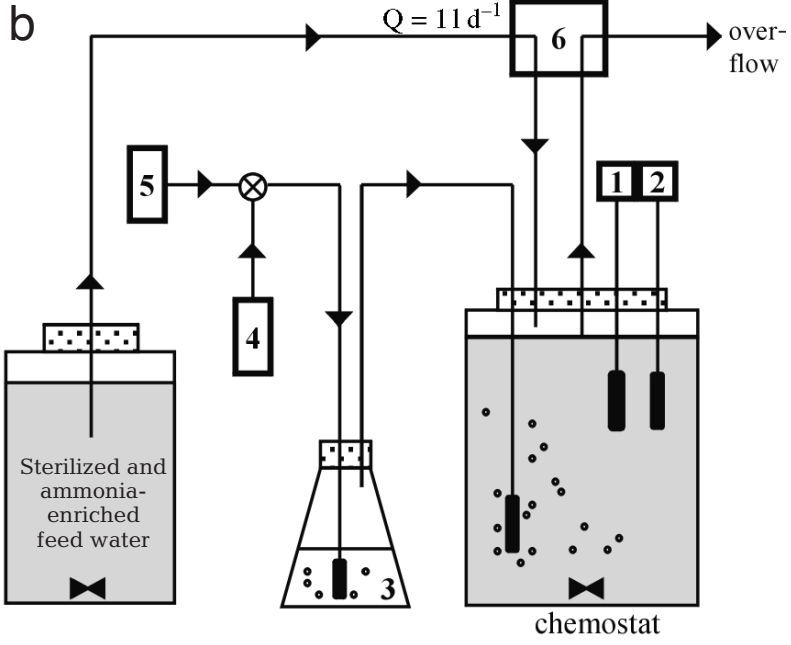

Fig. 1. Schematic representation of (a) batch and (b) chemostat setups. 1: oxygen meter, 2: pH meter, 3: carbonate buffer, 4: air pump, 5: nitrogen gas $\left(\mathrm{N}_{2}\right)$ bottle, 6: peristaltic pump. $Q$ : flow rate

tion ( 7 to $8 \mathrm{mg} \mathrm{l}^{-1}$ ) was measured continuously with an oxymeter and was maintained by a pump supplying air. $\mathrm{pH}$ was adjusted to between 7.5 and 8.0 by addition of phosphate buffer $\left(\mathrm{K}_{2} \mathrm{HPO}_{4} / \mathrm{KH}_{2} \mathrm{PO}_{4}\right)$. Nitrifying activity was checked by daily measurement of ammonia, nitrite and nitrate concentrations (see below). The 7 batch cultures were used for testing the effect of ammonium and nitrite on $\mathrm{N}_{2} \mathrm{O}$ production under conditions of oxic stress (see 'Effect of substrate concentration on $\mathrm{N}_{2} \mathrm{O}$ production in batch culture' below). Four other batches were set up to serve as initial cultures for the chemostat experiment.

Continuous culture experiments. On 4 occasions, 51 of the above batch cultures were used to start a chemostat experiment. After a maximum of $2 \mathrm{wk}$ under batch conditions, the nitrifying culture was used to start the continuous culture for 3 to $4 \mathrm{wk}$, until a typical steady state was reached in the chemostat (Fig. 1b). Dissolved mineral nitrogen concentrations were monitored daily (Fig. 1b).

The chemostat was continuously supplied with ammonium-enriched (25 to $30 \mathrm{mg} \mathrm{N}-\mathrm{NH}_{4}^{+} \mathrm{l}^{-1}$ ) sterilized Seine river water at a constant rate of $1 \mathrm{l} \mathrm{d}^{-1}$ with a peristaltic pump. The working volume of the chemostat was kept constant (2 l) by evacuation of an equal discharge of the culture; residence time in the chemostat was therefore $2 \mathrm{~d}$. The feed water was also collected from Duclair station. Feed water with an ammonia concentration similar to that of the treated effluent from the Achères WWTP was selected, in order to reproduce in situ conditions (i.e. input of ammonium by WWTP effluents into the Seine river). The feed water was phosphate buffered $\left(\mathrm{K}_{2} \mathrm{HPO}_{4} /\right.$ $\mathrm{KH}_{2} \mathrm{PO}_{4} ; 0.5 \mathrm{mM}$ final concentration, $\mathrm{pH} 7.5$ to 8 ) and had a nitrate concentration of between 5 and $8 \mathrm{mg}$ $\mathrm{N}^{-1}$. Both chemostat and feed-tank waters were magnetically stirred to maintain the particulate matter in suspension. The dissolved oxygen concentration, controlled with a combination of air pump and nitrogen gas bottle $\left(\mathrm{N}_{2}\right)$, was maintained at 7.5 to $8 \mathrm{mg} \mathrm{l}^{-1}$. When the nitrifying activity reached steady state (for at least $100 \mathrm{~h}$ ), different oxic stress conditions were imposed to study the nitrifier-denitrification (see 'Oxic stress and $\mathrm{N}_{2} \mathrm{O}$ production in continuous culture experiments' below).

Water analyses. Variability of DIN (dissolved inorganic nitrogen) was analysed daily on $20 \mathrm{ml}$ of the batch culture and chemostat water. Water was filtered (glass-fiber membrane, Whatman, GF/F) and frozen until analysis. Ammonium, nitrite and nitrate were determined spectrophotometrically; ammonium and nitrite after Rodier (1984), who proposed a Cd reduction of nitrate to nitrite.

For molecular biological analysis, 150 to $250 \mathrm{ml}$ of water (depending on the amount of suspended particulate matter [SPM]) was filtered through $0.22 \mu \mathrm{m}$ nitrocellulose filters (Durapore, diameter $=45 \mathrm{~mm}$ ) in triplicate, and the filters were frozen $\left(-20^{\circ} \mathrm{C}\right)$ prior to DNA extraction. Samples for DNA analysis were taken about once a week during one of the batch-continuous culture experiments.

Molecular study of the ammonia oxidizing population. DNA was extracted from the filters (see above), collected from one batch-chemostat experiment, by a bead-beating method using the FastDNA spin kit for soil (Bio 101) and purified on a Sephadex G-200 column. Nucleic acids were quantified as described by Cébron et al. (2004). 
All PCRs were conducted with CTO189F-654R primers after Kowalchuk et al. (1998) as described in Cébron et al. (2004), which allowed amplification of partial 16S rDNA sequences (465 bp) from $\beta$-subclass AOB. A nested PCR was run with the PCR products obtained from CTO primers as matrix DNA with a second primer-set, allowing the amplification of an internal fragment of 196 bp (Muyzer et al. 1993). PCR products (465 and 196 bp products) were loaded for DGGE (denaturing gradient gel electrophoresis) on polyacrylamide denaturant gels (gradient ranging from 30 to $55 \%$ ) according to Muyzer et al. (1993) and modified by Kowalchuk et al. (1998), under conditions used by Cébron et al. (2004). The DNA was stained with ethidium bromide and visualised by UV transillumination (Gel Doc 200, BioRad). Digital images of the gels were obtained with a CCD camera controlled by Quantity One software (BioRad). The DGGE bands were excised, re-amplified to confirm their purity, and sequenced for phylogenetic analyses (Clustal X, PHYLIP 3.5 package) (Cébron et al. 2004). The AOB present in the batch and chemostat were thus identified. The sequences determined in this study were

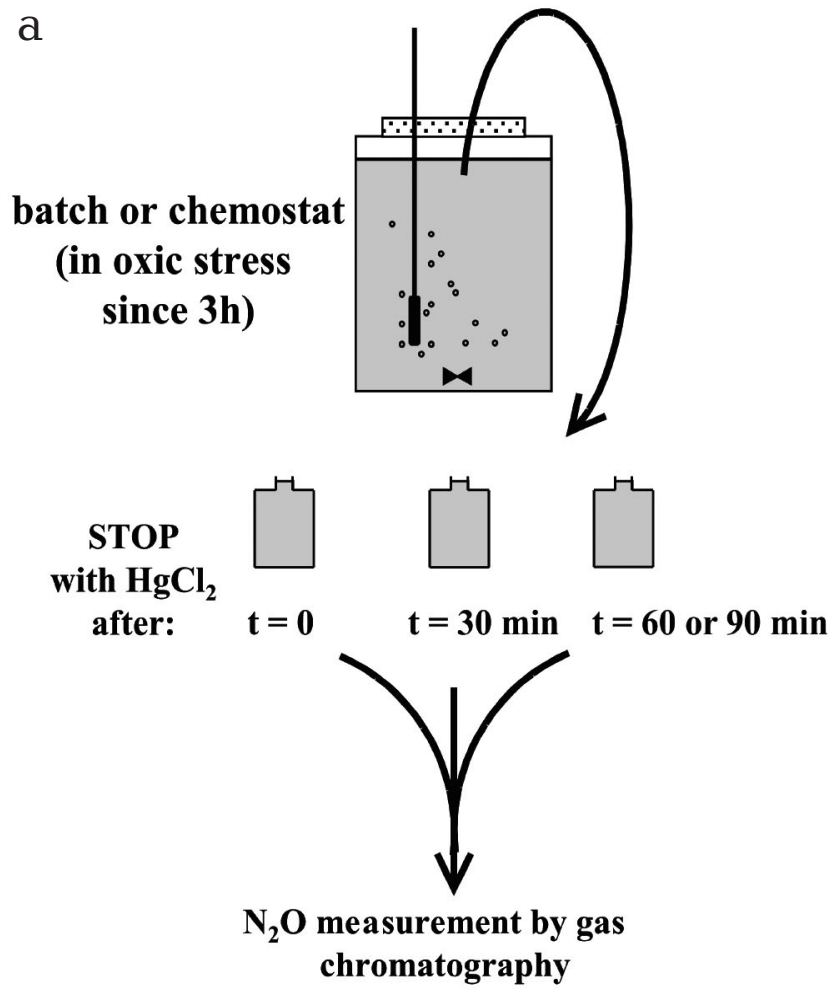

Fig. 2. (a) $\mathrm{N}_{2} \mathrm{O}$ production kinetics experiment procedure and (b) examples of results obtained for different conditions of oxygen, ammonium and nitrite concentrations. $\mathrm{N}_{2} \mathrm{O}$ production test with 2 different oxygenation conditions is shown for samples with (dotted line) and without (straight line) nitrification inhibitor addition deposited in the GenBank database under accession numbers AY648571 to AY648575.

Measurement of $\mathbf{N}_{2} \mathrm{O}$ production. $\mathrm{N}_{2} \mathrm{O}$ production was determined from samples taken from (1) batch cultures at the beginning of the stationary phase and (2) from continuous cultures at steady state. After $3 \mathrm{~h}$ of oxic stress, three $100 \mathrm{ml}$ glass serum vials were filled without shaking and without the inclusion of air bubbles, closed with a rubber cap and sealed (Fig. 2). The bacterial activity in one of the vials was immediately stopped with $\mathrm{HgCl}_{2} \quad(0.5 \%$ final concentration $)$ by injection with a syringe and needle to determine the initial $\mathrm{N}_{2} \mathrm{O}$ concentration (Fig. 2). A 2nd flask was poisoned after 30 min and a 3rd after 60 or 90 min (Fig. 2), during which time the oxygen concentration in the vial remained constant $\left( \pm 0.05 \mathrm{mg} \mathrm{O} \mathrm{O}_{2}^{-1}\right.$, checked for 1 experiment). Dissolved $\mathrm{N}_{2} \mathrm{O}$ was measured in triplicate by gas chromatography with electron capture

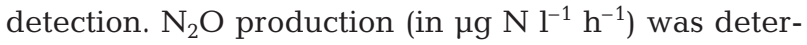
mined as the slope of the regression of concentrations against time (Fig. 2), and then expressed per AOB biomass unit. $\mathrm{N}_{2} \mathrm{O}$ production was measured at various oxygen levels, ammonia and nitrite treatment concen-

$\mathrm{b}$

b Oxic stress: $0.8 \mathrm{mg} \mathrm{O}_{2} \mathrm{l}^{-1}$
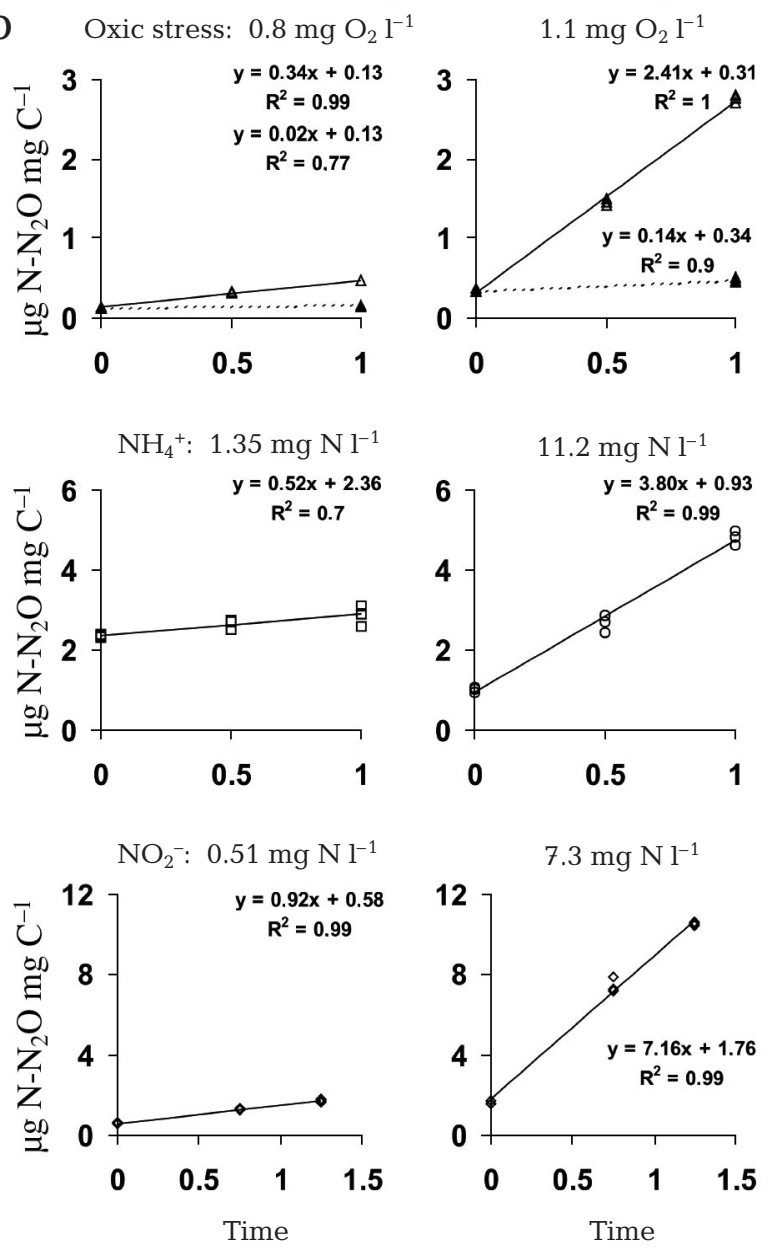
trations, and with or without specific nitrification inhibitors.

Oxic stress and $\mathrm{N}_{2} \mathrm{O}$ production in continuous culture experiments. Each of the 4 continuous cultures was subjected to 1, 2, 4 and 6 different oxic stress conditions, respectively (i.e. an abrupt decrease in dissolved oxygen to a chosen concentration, see Table 1). As mentioned above, the 3 samples for determining $\mathrm{N}_{2} \mathrm{O}$ production were taken after $3 \mathrm{~h}$ of oxic stress (see Fig. 2). Between each test of oxic stress, oxygen was readjusted to $7.5 \mathrm{mg} \mathrm{l}^{-1}$ in the continuous culture for at least $45 \mathrm{~h}$. Among the 4 continuous culture experiments, a wide range of oxic stress conditions was covered ( 0.25 to $4.5 \mathrm{mg} \mathrm{l}^{-1}$, Table 1 ); some similar oxygen conditions were tested several times so that the reproductibility of the results could be assessed. This allowed us to determine the dissolved oxygen concentration favorable for maximal $\mathrm{N}_{2} \mathrm{O}$ production. In each of the continuous culture experiments, $\mathrm{N}_{2} \mathrm{O}$ production at high oxygenation $\left(7.5 \mathrm{mg} \mathrm{l}^{-1}\right)$ was determined using the same protocol. Moreover, under 3 different oxic stress conditions $\left(0.8,1.1\right.$ and $\left.2.5 \mathrm{mg} \mathrm{O}_{2} \mathrm{l}^{-1}\right), \mathrm{N}_{2} \mathrm{O}$ production was measured with or without a specific nitrification inhibitor in order to confirm that it was really produced by the nitrifier-denitrification activity of AOB (see Fig. 2). Allylthiourea (10 $\mathrm{mg} \mathrm{l}^{-1}$ final concentration) was used as an inhibitor: this substance affects the nitrification by chelation of copper at the catalytic site of the ammonium mono-oxygenase enzyme.

Effect of substrate concentration on $\mathrm{N}_{2} \mathrm{O}$ production in batch culture. The 7 batch cultures were run until ammonium ( 2 to 3 additions) and nitrite were fully oxidized (stationary phase). Each of these batch cultures was then divided into a number of smaller batches of 1.51 (from 2 to 6) supplied in parallel with a combination of air and $\mathrm{N}_{2}$, in which different substrate concentrations were tested (Fig. 1a, Table 2). In order to test the effect of nitrite concentrations on the $\mathrm{N}_{2} \mathrm{O}$ production rate, ammonium concentration was added to nonlimiting concentration from 19.9 to $27.9 \mathrm{mg} \mathrm{N}-\mathrm{NH}_{4} \mathrm{l}^{-1}$, whereas nitrite was added in a range from 0.08 to
Table 2. Description of 7 batch experiments and variable experimental conditions. (a) Batch 7 is without oxic stress (dissolved oxygen concentration $7.5 \mathrm{mg} \mathrm{l}^{-1}$ ); all other batches are in oxic stress (dissolved oxygen concentration $1.25 \mathrm{mg} \mathrm{l}^{-1}$ ). (b) Batches 1 and 3: low nitrite and ammonium concentrations. (c) Batches 1-3 and 6: nitrite effect test with different nitrite concentrations and a high ammonium concentration. (d) Batches 4-6: ammonium effect test with different ammonium concentrations and a high nitrite concentration

\begin{tabular}{|c|c|c|}
\hline Batch no. & $\mathrm{NO}_{2}\left(\mathrm{mg} \mathrm{l}^{-1}\right)$ & $\mathrm{NH}_{4}\left(\mathrm{mg} \mathrm{l}^{-1}\right)$ \\
\hline \multicolumn{3}{|c|}{ (a) Test without oxic stress } \\
\hline \multirow[t]{4}{*}{7} & 0.04 & 0.11 \\
\hline & 3.2 & 25.3 \\
\hline & 5.5 & 12.7 \\
\hline & 8.1 & 4.8 \\
\hline \multicolumn{3}{|c|}{ (b) Testing with low $\mathrm{NO}_{2}$ and $\mathrm{NH}_{4}$ concentrations } \\
\hline 1 & 0.03 & 0.12 \\
\hline 3 & 0.39 & 1.1 \\
\hline \multicolumn{3}{|c|}{ (c) Testing a range of $\mathrm{NO}_{2}$ concentrations } \\
\hline \multirow[t]{5}{*}{1} & 0.08 & 27.4 \\
\hline & 0.51 & 25.4 \\
\hline & 1.48 & 25.5 \\
\hline & 3.43 & 27.9 \\
\hline & 7.26 & 27.6 \\
\hline \multirow[t]{2}{*}{2} & 20.0 & 26.4 \\
\hline & 27.9 & 25.3 \\
\hline \multirow[t]{3}{*}{3} & 1.19 & 19.9 \\
\hline & 3.83 & 19.9 \\
\hline & 14.7 & 26.9 \\
\hline \multirow[t]{3}{*}{6} & 3.99 & 21.2 \\
\hline & 6.3 & 23.5 \\
\hline & 12.2 & 22.1 \\
\hline \multicolumn{3}{|c|}{ (d) Testing a range of $\mathrm{NH}_{4}$ concentrations } \\
\hline \multirow[t]{4}{*}{4} & 3.18 & 0.6 \\
\hline & 3.25 & 1.37 \\
\hline & 3.18 & 2.8 \\
\hline & 3.23 & 5.9 \\
\hline \multirow[t]{5}{*}{5} & 3.69 & 0.08 \\
\hline & 3.9 & 0.71 \\
\hline & 4.1 & 2.54 \\
\hline & 4.04 & 5.73 \\
\hline & 4.03 & 16.9 \\
\hline 6 & 4.3 & 0.11 \\
\hline
\end{tabular}

Table 1. Characteristics of the steady state reached by 4 continuous cultures of natural assemblages of nitrifying bacteria from the Seine estuary. Values of oxic stress imposed on each steady state culture are presented in chronological order. Dilution rate for all 4 cultures was $0.021 \mathrm{~h}^{-1}$. AOB: ammonia oxidizing bacteria; NOB: nitrite oxidizing bacteria

\begin{tabular}{|c|c|c|c|c|c|c|c|}
\hline \multirow[t]{2}{*}{ No. } & \multicolumn{2}{|c|}{$\begin{array}{l}\text { Feeder conc. } \\
\left(\mathrm{mg} \mathrm{N} \mathrm{l}^{-1}\right)\end{array}$} & \multicolumn{2}{|c|}{$\begin{array}{l}\text { Culture conc. } \\
\left(\mathrm{mg} \mathrm{N} \mathrm{l}^{-1}\right)\end{array}$} & \multicolumn{2}{|c|}{$\begin{array}{l}\text { Estimated biomass } \\
\qquad\left(\mathrm{mg} \mathrm{Cl}^{-1}\right)\end{array}$} & \multirow[t]{2}{*}{$\begin{array}{l}\text { Oxic stress values } \\
\qquad\left(\mathrm{mg} \mathrm{O}_{2} \mathrm{l}^{-1}\right)\end{array}$} \\
\hline & $\mathrm{NH}_{4}$ & $\mathrm{NO}_{3}$ & $\mathrm{NH}_{4}$ & $\mathrm{NO}_{3}$ & AOB & NOB & \\
\hline 1 & 25.5 & 10.3 & 4.2 & 32.6 & 1.39 & 0.25 & 3 \\
\hline 2 & 26.2 & 12.7 & 9.8 & 27.9 & 1.66 & 0.15 & $1.25,4.5$ \\
\hline 3 & 29.2 & 8.7 & 5.7 & 28.2 & 1.89 & 0.47 & $7.5,2,1.5^{\mathrm{a}}, 0.5$ \\
\hline 4 & 25.9 & 6.5 & 0.5 & 33.6 & 1.76 & 0.43 & $1.1^{\mathrm{a}}, 0.25,1.4,0.4,2.5,0.8^{\mathrm{a}}$ \\
\hline
\end{tabular}


$27.90 \mathrm{mg} \mathrm{N}-\mathrm{NO}_{2}{ }^{-} \mathrm{l}^{-1}$ (13 different nitrite concentrations tested, see Table 2). Conversely, in order to test the effect of ammonium concentration on $\mathrm{N}_{2} \mathrm{O}$ production rate, nitrite was added to a final concentration of 3.18 to $4.3 \mathrm{mg} \mathrm{N}-\mathrm{NO}_{2} \mathrm{l}^{-1}$, whereas ammonia was added in a range from 0.08 to $16.90 \mathrm{mg} \mathrm{N}-\mathrm{NH}_{4}{ }^{+} \mathrm{l}^{-1}$ (12 different ammonium concentrations tested, see Table 2). We also tested the effect of simultaneous low concentrations of the 2 substrates on the rate of $\mathrm{N}_{2} \mathrm{O}$ production (Batch no. 1, see Table 2).

One hour after substrate addition, batches were subjected to oxic stress by reducing oxygen to $1.25 \mathrm{mg} \mathrm{l}^{-1}$ for $3 \mathrm{~h}$, after which three $100 \mathrm{ml}$ samples were taken for determining $\mathrm{N}_{2} \mathrm{O}$ production (see above). Again, the $\mathrm{N}_{2} \mathrm{O}$ production was measured in batch culture experiments under high oxygen conditions $\left(7.5 \mathrm{mg} \mathrm{l}^{-1}\right)$ under 4 different substrate conditions (Batch no. 7 , see Table 2).

Modeling bacterial growth and activity in culture. In closed batch culture, nitrifiers grew until ammonium and nitrite were exhausted. In continuous culture, microorganisms grew on ammonium and nitrite with constant inflow of ammonium. The outflow was a blend of nutrients and microorganisms. Assuming a stable bacterial composition among all experiments, the observed variations of substrate and product concentrations can be modelled using constant kinetic parameters. We applied the classical conceptual schema of 2 steps: (1) ammonium $\left(\mathrm{NH}_{4}\right)$ oxidation to nitrite $\left(\mathrm{NO}_{2}\right)$ by $\mathrm{AOB}$, and (2) nitrite oxidation to nitrate $\left(\mathrm{NO}_{3}\right)$ by nitrite oxidizing bacteria (NOB), using parameter ranges determined by Brion \& Billen (1998) (Table 3).

For both batch and continuous cultures, the following differential equations were formulated:

$$
\begin{aligned}
\frac{\mathrm{dNH}}{4}=- & -\frac{\mu_{\operatorname{maxAOB}}}{Y_{\mathrm{AOB}}} \cdot \frac{\mathrm{NH}_{4}}{\left(\mathrm{NH}_{4}+K_{\mathrm{NH}_{4}}\right)} \cdot \frac{\mathrm{O}_{2}}{\left(\mathrm{O}_{2}+K_{\mathrm{O}_{2}}\right)} \cdot B M a+\frac{Q}{V} \cdot\left(\mathrm{NH}_{4}^{\circ}-\mathrm{NH}_{4}\right) \\
\frac{\mathrm{dNO} O_{2}}{\mathrm{~d} t}= & \frac{\mu_{\operatorname{maxAOB}}}{Y_{\mathrm{AOB}}} \cdot \frac{\mathrm{NH}_{4}}{\left(\mathrm{NH}_{4}+K_{\mathrm{NH}_{4}}\right)} \cdot \frac{\mathrm{O}_{2}}{\left(\mathrm{O}_{2}+K_{\mathrm{O}_{2}}\right)} \cdot B M a+\frac{Q}{V} \cdot\left(\mathrm{NO}_{2}{ }^{\circ}-\mathrm{NO}_{2}\right) \\
& -\frac{\mu_{\operatorname{maxNOB}}}{Y_{\mathrm{NOB}}} \cdot \frac{\mathrm{NO}_{2}}{\left(\mathrm{NO}_{2}+K_{\mathrm{NO}_{2}}\right)} \cdot \frac{\mathrm{O}_{2}}{\left(\mathrm{O}_{2}+K_{\mathrm{O}_{2}}\right)} \cdot B M n \\
\frac{\mathrm{dNO}}{\mathrm{d} t}=- & \frac{\mu_{\operatorname{maxNOB}}}{Y_{\mathrm{NOB}}} \cdot \frac{\mathrm{NO}_{2}}{\left(\mathrm{NO}_{2}+K_{\mathrm{NO}_{2}}\right)} \cdot \frac{\mathrm{O}_{2}}{\left(\mathrm{O}_{2}+K_{\mathrm{O}_{2}}^{\prime}\right)} \cdot B M n+\frac{Q}{V} \cdot\left(\mathrm{NO}_{3}^{\circ}-\mathrm{NO}_{3}\right) \\
\frac{\mathrm{d} B M a}{\mathrm{~d} t}= & -\frac{\mu_{\operatorname{maxAOB}} \cdot \mathrm{NH}_{4}}{\left(\mathrm{NH}_{4}+K_{\mathrm{NH}_{4}}\right)} \cdot \frac{\mathrm{O}_{2}}{\left(\mathrm{O}_{2}+K_{\mathrm{O}_{2}}\right)} \cdot B M a-\frac{Q}{V} \cdot B M a-k d \cdot B M a \\
\frac{\mathrm{d} B M n}{\mathrm{~d} t}= & \frac{\mu_{\operatorname{maxNOB}} \cdot \mathrm{NO}_{2}}{\left(\mathrm{NO}_{2}+K_{\mathrm{NO}_{2}}\right)} \cdot \frac{\mathrm{O}_{2}}{\left(\mathrm{O}_{2}+K_{\mathrm{O}_{2}}\right)} \cdot B M n-\frac{Q}{V} \cdot B M n-k d \cdot B M n
\end{aligned}
$$

where $\mu_{\max A O B}$ and $\mu_{\operatorname{maxNOB}}$ are the maximum growth rates $\left(\mathrm{h}^{-1}\right)$ of $\mathrm{AOB}$ and $\mathrm{NOB}$, respectively, $Y_{\mathrm{AOB}}$ and
$Y_{\mathrm{NOB}}$ are their growth yields ( $\mathrm{mg} \mathrm{C} \mathrm{mg} \mathrm{N}^{-1}$ ), $K_{\mathrm{NH}_{4}}$ and $K_{\mathrm{O}_{2}}$ are the half-saturation constants for ammonium $\left(\mathrm{mg} \mathrm{N} \mathrm{l}^{-1}\right.$ ) and oxygen ( $\mathrm{mg} \mathrm{O}_{2} \mathrm{l}^{-1}$ ) for $\mathrm{AOB}, K_{\mathrm{NO}_{2}}$ and $K^{\prime} \mathrm{O}_{2}$ are the half-saturation constant for nitrite and oxygen for NOB, $k d$ is an adjusted first order bacterial mortality constant, $Q$ is the flow rate, and $V$ the culture volume. $Q$ is 0 in batch culture. $\mathrm{NH}_{4}{ }^{\circ}$ and $\mathrm{NO}_{2}{ }^{\circ}$ are ammonium and nitrite concentrations in the feed water, and $\mathrm{NH}_{4}$ and $\mathrm{NO}_{2}$ are the concentrations in the culture. These equations were used to model the nitrifying activities in batch and continuous cultures. The ammonia and nitrite oxidizer biomasses, $B M a$ and $B M n$, respectively, were then deduced from these results.

$\mathrm{N}_{2} \mathrm{O}$ production formulation. We hypothesized that $\mathrm{N}_{2} \mathrm{O}$ produced during nitrifier-denitrification process results from the oxidation of $\mathrm{NH}_{4}$ by $\mathrm{AOB}$, using $\mathrm{NO}_{2}{ }^{-}$ as an alternative electron acceptor at low oxygen concentrations. It was therefore logical to represent the kinetics of the processes according to the following relationship:

$\mathrm{N}_{2} \mathrm{O}$ production $=V_{\operatorname{maxN}_{2} \mathrm{O}} \cdot \frac{\mathrm{NH}_{4}}{\left(\mathrm{NH}_{4}+K_{\mathrm{NH}_{4}}^{\prime}\right)} \cdot \frac{\mathrm{NO}_{2}}{\left(\mathrm{NO}_{2}+K_{\mathrm{NO}_{2}}^{\prime}\right)} \cdot B M a$

where $V_{\operatorname{maxN}_{2} \mathrm{O}}$ is the specific rate of $\mathrm{N}_{2} \mathrm{O}$ production (mg N mg C ${ }^{-1}$ ), and $K_{\mathrm{NH}_{4}}^{\prime}$ and $K_{\mathrm{NO}_{2}}^{\prime}$ are the halfsaturation constants for ammonium oxidation to $\mathrm{N}_{2} \mathrm{O}$ with respect to ammonium and nitrite, respectively.

\section{RESULTS}

\section{Nitrification in batch and continuous culture experiments}

\section{Batch experiments}

An example of representative DIN variations in one of the batch experiments is shown in Fig. 3, where high oxygenation ( 7.5 to $8 \mathrm{mg} \mathrm{O}_{2} \mathrm{l}^{-1}$ ) and ammoniaenrichment (30 to $40 \mathrm{mg} \mathrm{N}-\mathrm{NH}_{4}{ }^{+} \mathrm{l}^{-1}$ ) led to complete consumption of the ammonium accompanied by nitrite and nitrate production. During the experiment, extra ammonium was added on 3 occasions when ammonium was depleted (at the start of the experiment and after 140 and $190 \mathrm{~h}$ ). For the first $50 \mathrm{~h}$, the culture followed a lag-phase with little DIN variation. Complete consumption of the ammonia, accompanied by nitrite and nitrate production, was observed throughout the next $100 \mathrm{~h}$. After less than $2 \mathrm{wk}$ in batch, the nitrifying culture was subsequently used as a starting culture for chemostat experiments or divided into smaller batches (1.5 l) for studies of $\mathrm{N}_{2} \mathrm{O}$ production in a range of ammonium and nitrite concentrations (cf. Fig. 1a, Table 2). 


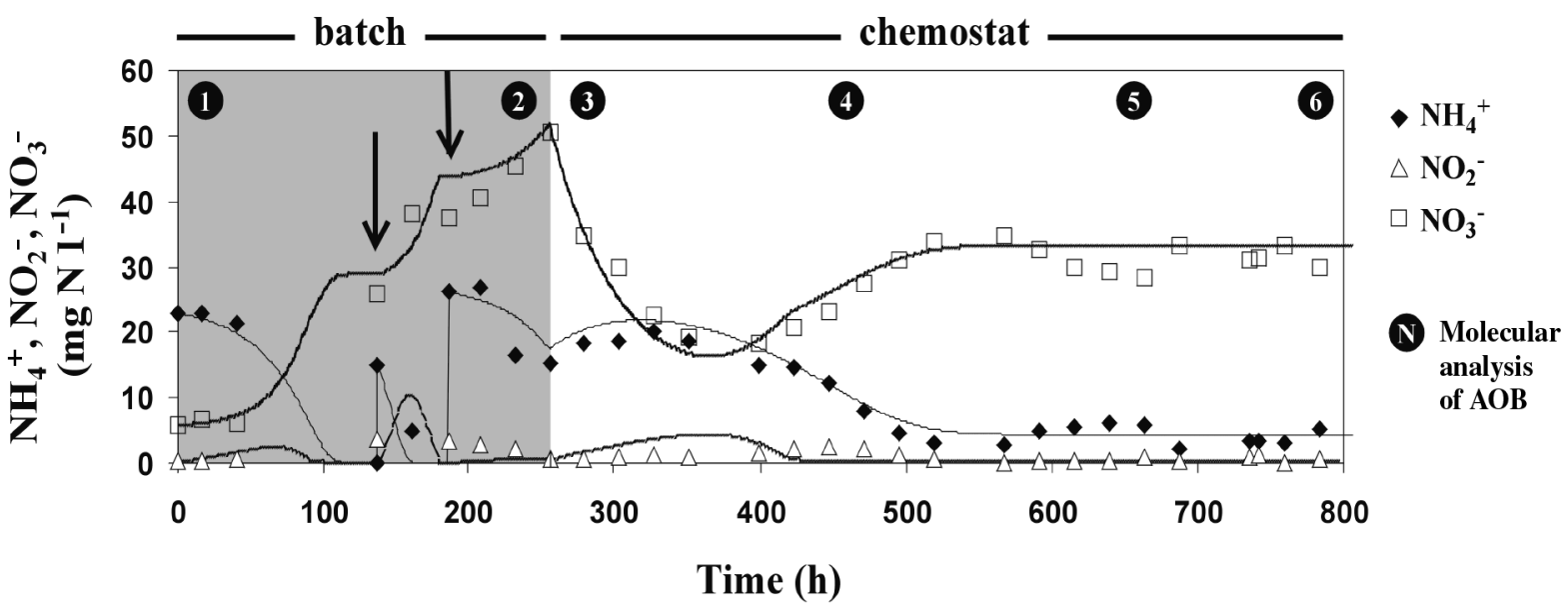

Fig. 3. Example of ammonium $\left(\mathrm{N}-\mathrm{NH}_{4}{ }^{+}\right)$, nitrite $\left(\mathrm{N}-\mathrm{NO}_{2}{ }^{-}\right)$and nitrate $\left(\mathrm{N}-\mathrm{NO}_{3}{ }^{-}\right)$concentrations during 1 batch and 1 chemostat experiment (experimental points are represented). Curves are derived from modeling the nitrogen concentrations in batch and chemostat stages with 1 set of kinetic parameters (see Table 1). Numbers 1 to 6 indicate sampling times for molecular analyses

\section{Continuous culture experiment}

The starting conditions of the continuous culture experiment were the final conditions of the corresponding batch culture (see Fig. 3). The variations in DIN concentration in this example of continuous culture were similar to those observed for the 3 other continuous culture experiments, and 3 stages were identified (Fig. 3): (1) During the first $100 \mathrm{~h}$ in chemostat (see Fig. 3, from time 250 to 350 h), we observed a dilution by the inflowing feed water that contained (among the 4 experiments) between 25.5 and $29.2 \mathrm{mg}$ $\mathrm{N}-\mathrm{NH}_{4}{ }^{+} \mathrm{l}^{-1}$, and between 6.5 and $12.7 \mathrm{mg} \mathrm{N}-\mathrm{NO}_{3}{ }^{-} \mathrm{l}^{-1}$, depending on the initial Seine water sample (Fig. 3, Table 1). (2) Between 350 and 500 h, nitrifying activity began again as indicated by ammonia consumption and nitrate production. The nitrite concentration either decreased or remained low. (3) At around $500 \mathrm{~h}$, a steady state was reached, with relatively constant nitrifying activity (Fig. 3, Table 1) and ammonium and nitrate concentrations at equilibrium (Table 1). After a minimum of $100 \mathrm{~h}$ of steady state, culture was submitted to multiple oxic stresses.

\section{Modeling the dynamics of nitrifying bacteria in batch and continuous cultures}

Using the equations given in 'Materials and methods', and values for growth yield $Y(0.08$ and $0.02 \mathrm{mg} \mathrm{C}$ mg $\mathrm{N}^{-1}$ for AOB and NOB, respectively) (Table 3), we accurately simulated the time course of both batch and continuous cultures (Fig. 3). A set of parameter values was adjusted (Table 3 ) so that simulations could fit the experimental values. For the batch cultures we adjusted the bacterial mortality rate to $0.001 \mathrm{~h}^{-1}$ in the presence of high substrate concentration, but we had to increase it 10 times during periods of low substrate concentration in order to account for the observation of a rapid loss of activity after substrate depletion.

With these simulations, we were able to estimate AOB biomass at the end of batch culture (nitrifying biomass varied from 0.37 to $0.53 \mathrm{mg} \mathrm{C}^{-1}$ ) and during the steady state of continuous cultures (Fig. 3, Table 1). Results were then expressed in units of bacterial biomass in order to compare among various experiments.

The range of parameter values found here for mixed natural populations (Table 1 ) is relatively close to the

Table 3. Values of growth kinetic parameters of ammonium oxidizing (AOB) and nitrite oxidizing bacteria (NOB) under oxic conditions for mixed natural populations. Values reported by Brion \& Billen (1998) for pure cultures are given in parentheses

\begin{tabular}{|c|c|c|c|c|c|c|}
\hline & $\begin{array}{l}\text { Max. growth rate } \\
\qquad\left(\mu_{\max }, h^{-1}\right)\end{array}$ & 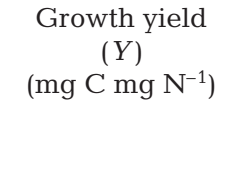 & $\begin{array}{l}\text { Half-saturation } \\
\text { constant } \\
\text { for substrate } \\
\left(K_{\mathrm{NH}_{4}} / K_{\mathrm{NO}_{2}}\right) \\
\left(\mathrm{mg} \mathrm{N} \mathrm{l}^{-1}\right)\end{array}$ & $\begin{array}{l}\text { Half-saturation } \\
\text { constant } \\
\text { for oxidant } \\
\left(K_{\mathrm{O}_{2}} / K^{\prime} \mathrm{O}_{2}\right) \\
\left(\mathrm{mg} \mathrm{O}_{2} \mathrm{I}^{-1}\right)\end{array}$ & $\begin{array}{l}\text { Specific activity } \\
\left(V_{\max }=\mu_{\max } Y^{-1}\right) \\
\left(\mathrm{mg} \mathrm{N} \mathrm{mg} \mathrm{C}^{-1} \mathrm{~h}^{-1}\right)\end{array}$ & $\begin{array}{l}\text { Mortality rate } \\
\quad(k d)\left(\mathrm{h}^{-1}\right)\end{array}$ \\
\hline AOB & $0.028-0.05(0.05)$ & $0.05-0.077(0.09)$ & $0.8-1.5(1.5)$ & $0.2-0.6(0.6)$ & $0.36-1(0.70)$ & 0.001 \\
\hline NOB & $0.051-0.064(0.05)$ & $0.01-0.02(0.02)$ & $0.001-0.028(0.03)$ & $0.8-2.4(1.1)$ & $2.55-6.4(3)$ & 0.001 \\
\hline
\end{tabular}


range reported by Brion \& Billen (1998) on pure cultures $\left(\mu_{\text {max }}: 0.04\right.$ and $0.06 \mathrm{~h}^{-1}$ for AOB and NOB, respectively; half-saturation constants $\left(K_{s}\right)$ : 3 and $0.3 \mathrm{mg} \mathrm{N}^{-1}$ for ammonia and nitrite, respectively, Table 3).

\section{AOB population diversity}

It is worth noting that the structure of AOB populations in the lower Seine river is relatively constant throughout the summer period and from year to year (Cébron et al. 2004). We studied changes in the diversity of populations of AOB in the batch and continuous cultures, using DGGE analyses to compare experimental results with in situ diversities investigated by Cébron et al. (2004). We show here only the results from nested PCR, as DGGE bands obtained from PCR products generated by the CTO primer set were not well defined. DGGE profiles obtained from nested PCR (Fig. 4a) represent populations present at the beginning and the end of the batch culture in lanes 1 and 2, respectively, while lanes 3 to 6 represent populations present during the continuous culture (cf. sampling times shown in Fig. 3). The bands recovered in this study were the same as those found in the natural environment (Cébron et al. 2004). We have already demonstrated that phylogenetic analysis of these small length fragments (196 bp) gives results comparable to those obtained from 465 bp fragment analysis (Cébron et al. 2004).

a)

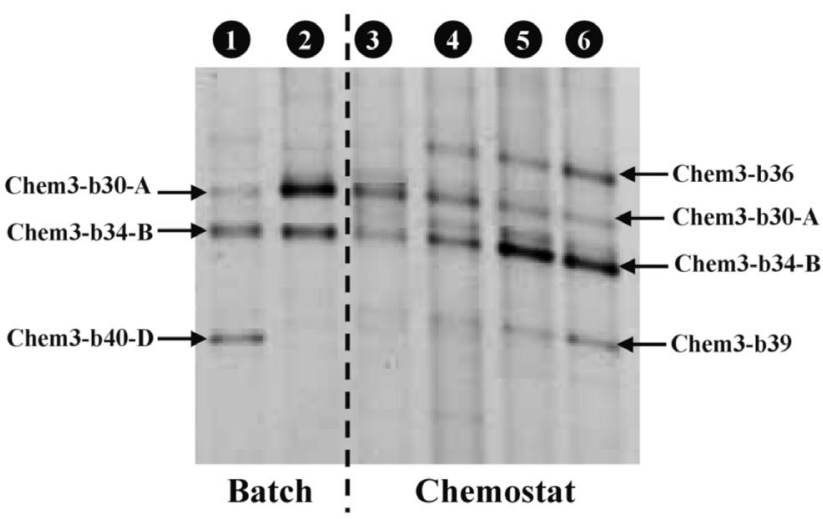

During the batch experiment the bacterial populations showed only slight changes in composition (Fig. 4). At the beginning of the batch culture, the community was composed of 2 major AOBs represented by bands Chem3-b30-A and Chem3-b34-B (sequencing revealed that band Chem3-b40-D is not an AOB species; Cébron et al. 2004). These 2 bacteria are affiliated to the Nitrosomonas oligotropha and $N$. ureae-like bacteria, belonging to Cluster 6a of $\beta$-Proteobacteria (Fig. 4b). The same bacteria were still present at the end of the nitrifying batch culture (after more than $200 \mathrm{~h}$ ), but by then the Chem3-b30-A band had appeared as the dominant bacteria. The non-AOB species disappeared, confirming selection for nitrifying bacteria.

During the continuous culture, the AOB population diversified, with an increase from 2 to 4 unique bands within 600 h. Bands Chem3-b30-A and Chem3-b34-B remained, but 2 new bands (Chem3-b36 and Chem3b39) appeared during steady state. These 2 new bands are affiliated to the same Cluster 6a as the other bacteria, and are even closer to Nitrosomonas oligotropha and $N$. ureae. During steady state, the major band was Chem3-b34-B.

\section{Effect of dissolved oxygen concentration on $\mathrm{N}_{2} \mathrm{O}$ production}

All $\mathrm{N}_{2} \mathrm{O}$ production rates given here were derived from significant linear relationships between $\mathrm{N}_{2} \mathrm{O}$

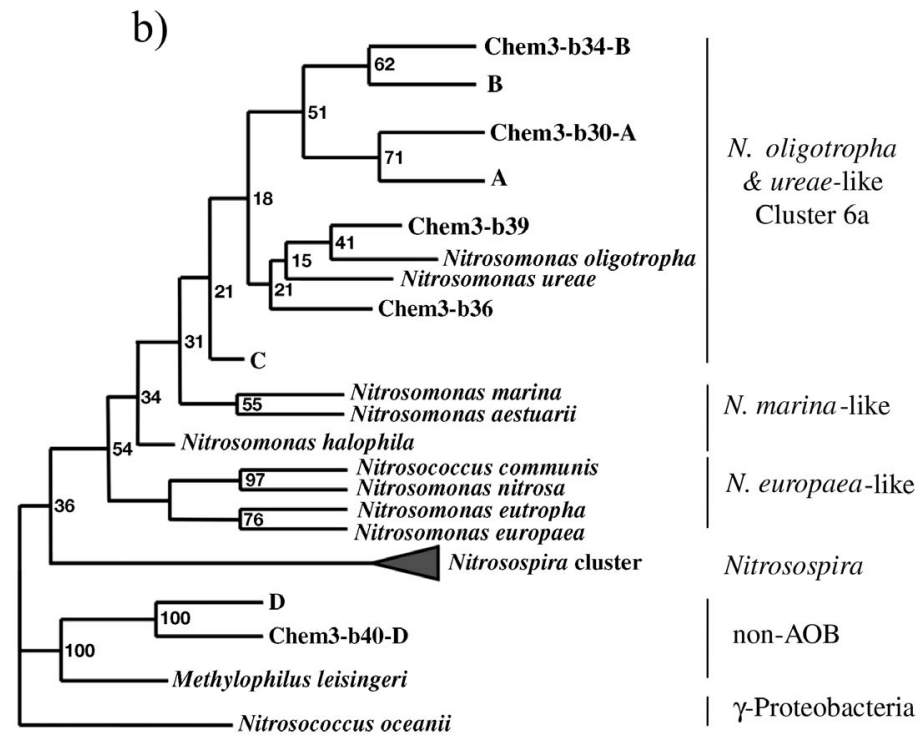

Fig. 4. (a) DGGE profile of AOB of the $\beta$-subclass of Proteobacteria in batch and chemostat samples. Lane numbers correspond to 6 different sampling times in batch and chemostat (cf. Fig. 3). All bands have the prefix Chem3 followed by the band number. Where present, letters A, B or D refer to Cébron et al. (2004). (b) Phylogeny of each AOB, presented as a neighbor-joining tree based on comparisons of 152 bp of 16S rRNA gene sequences. The tree is rooted with AOB belonging to the $\gamma$-subclass of Proteobacteria 
concentrations and incubation time $\left(\mathrm{r}^{2}\right.$ above 0.88 , cf. Fig. 2); values, obtained from 13 different dissolved oxygen concentrations ranging from 0.25 to $7.5 \mathrm{mg} \mathrm{l}^{-1}$, and normalized to AOB biomass ( $\mathrm{mg} \mathrm{C}^{-1}$ ), ranged

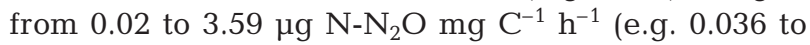
$5.96 \mu \mathrm{g} \mathrm{N}-\mathrm{N}_{2} \mathrm{O} \mathrm{l}^{-1} \mathrm{~h}^{-1}$, Fig. 5).

For oxygen concentrations above $2 \mathrm{mg} \mathrm{l}^{-1}$, a basal $\mathrm{N}_{2} \mathrm{O}$ production of 0.02 to $0.36 \mu \mathrm{g} \mathrm{N}-\mathrm{N}_{2} \mathrm{O} \mathrm{mg} \mathrm{C} \mathrm{Ch}^{-1} \mathrm{~h}^{-1}$ was observed (Fig. 5). A reduction in oxygen concentration below $2 \mathrm{mg} \mathrm{l}^{-1}$ to $1.4 \mathrm{mg} \mathrm{l}^{-1}$ induced a $\mathrm{N}_{2} \mathrm{O}$ production increase up to $1.22 \mu \mathrm{g} \mathrm{N}-\mathrm{N}_{2} \mathrm{O} \mathrm{mg} \mathrm{C}^{-1} \mathrm{~h}^{-1}$. However, when oxygen concentrations were further decreased to 1.1-1.25 mg $\mathrm{O}_{2} \mathrm{l}^{-1}, \mathrm{~N}_{2} \mathrm{O}$ production increased dramatically to $2.4-3.6 \mu \mathrm{g} \mathrm{N}-\mathrm{N}_{2} \mathrm{O} \mathrm{mg} \mathrm{C}^{-1}$ $\mathrm{h}^{-1}$. Below $0.8 \mathrm{mg} \mathrm{O}_{2} \mathrm{l}^{-1}, \mathrm{~N}_{2} \mathrm{O}$ production became low again. When $\mathrm{N}_{2} \mathrm{O}$ production was plotted as a function of oxygen concentration, a peak in $\mathrm{N}_{2} \mathrm{O}$ production was observed within a narrow dissolved oxygen range (1.1 to $1.25 \mathrm{mg} \mathrm{O}_{2} \mathrm{l}^{-1}$ ).

Addition of the nitrification inhibitor at 3 oxygen concentrations $\left(0.8,1.1\right.$ and $\left.2.5 \mathrm{mg} \mathrm{l}^{-1}\right)$ reduced the $\mathrm{N}_{2} \mathrm{O}$ production to very low values compared to production without the inhibitor, confirming that $\mathrm{N}_{2} \mathrm{O}$ produced under the experimental conditions was derived mainly from nitrification (Fig. 2).

\section{Effect of ammonia and nitrite concentrations on $\mathrm{N}_{2} \mathrm{O}$ production}

Our hypothesis that $\mathrm{N}_{2} \mathrm{O}$ production depends on both ammonium and nitrite concentrations was tested in batch cultures at the oxygen concentration that produced maximum $\mathrm{N}_{2} \mathrm{O}\left(1.25 \mathrm{mg} \mathrm{O}_{2} \mathrm{l}^{-1}\right.$ ) (see Table 2). To compare results among different batch cultures, we calculated the nitrifying biomass and determined that biomass in the different batch cultures varied from 0.37 to $0.53 \mathrm{mg} \mathrm{Cl}^{-1}$.

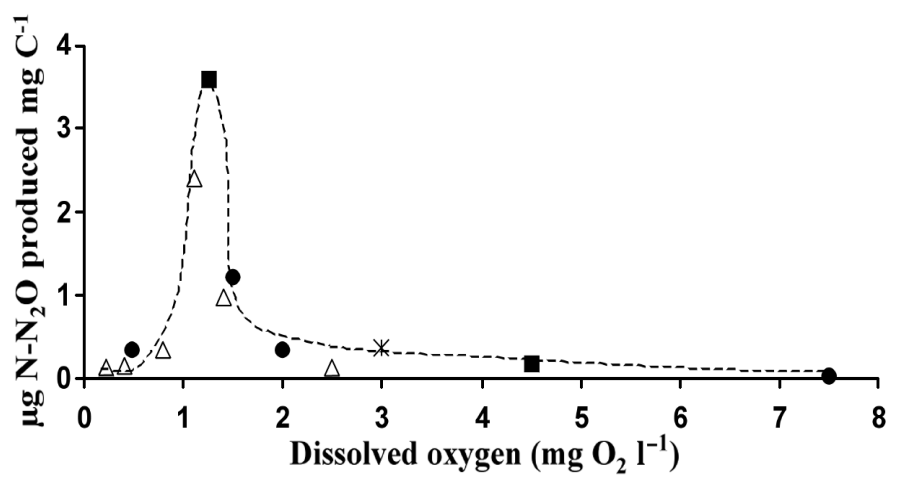

Fig. 5. Relationship between nitrous oxide production and oxygen concentration in chemostat experiments. Different symbols represent the 4 chemostat experiments

\section{Effect of ammonia}

The effect of the 12 ammonia concentrations was tested while supplying nitrite at a constant concentration of 3.18 to $4.3 \mathrm{mg} \mathrm{N}-\mathrm{NO}_{2}^{-} \mathrm{l}^{-1}$, which was assumed to be non-limiting. The 5 lowest ammonia concentrations led to low $\mathrm{N}_{2} \mathrm{O}$ production (Fig. 6), with higher variability as shown by the relatively low, statistically significant correlation coefficient $\left(\mathrm{r}^{2}=0.65\right.$ to 0.84$)$. Note that for oxygenation of $7.5 \mathrm{mg} \mathrm{O} \mathrm{O}_{2} \mathrm{l}^{-1}$ with similar ammonia and nitrite concentrations, $\mathrm{N}_{2} \mathrm{O}$ production was close to 0 (data not shown).

When plotted against ammonia concentration, $\mathrm{N}_{2} \mathrm{O}$ production showed a regular increase at low concentration, before reaching a plateau that represented the maximum rate of $\mathrm{N}_{2} \mathrm{O}$ production in the experimental conditions, up to $3.8 \mu \mathrm{g} \mathrm{N}-\mathrm{N}_{2} \mathrm{O} \mathrm{mg} \mathrm{C}^{-1} \mathrm{~h}^{-1}$ (i.e. $1.4 \mu \mathrm{g}$ $\mathrm{N}-\mathrm{N}_{2} \mathrm{O}^{-1} \mathrm{~h}^{-1}$ ) (Fig. 6). Observations could be fitted by hyperbolic curves (Michaëlis-Menten) that illustrated the enzymatic kinetics of $\mathrm{N}_{2} \mathrm{O}$ production, and $V_{\max }$ and $K$ parameters were then determined (Fig. 6). $V_{\text {maxN }_{2} \mathrm{O}}$ (maximum rate of $\mathrm{N}_{2} \mathrm{O}$ emission) ranged from 4 to $4.3 \mu \mathrm{g} \mathrm{N}-\mathrm{N}_{2} \mathrm{O} \mathrm{mg} \mathrm{C} \mathrm{C}^{-1} \mathrm{~h}^{-1}$, whereas $K_{\mathrm{NH}_{4}}^{\prime}$ (halfsaturation constant) varied from 1.5 to $3 \mathrm{mg} \mathrm{N}-\mathrm{NH}_{4}{ }^{+} \mathrm{l}^{-1}$.

\section{Effect of nitrite}

Conversely, in a separate set of experiments, ammonia concentration was maintained at saturating values close to $20 \mathrm{mg} \mathrm{N}-\mathrm{NH}_{4}{ }^{+} \mathrm{l}^{-1}$ in order to investigate the effect of nitrite limitation (Fig. 7). The maximum spe-

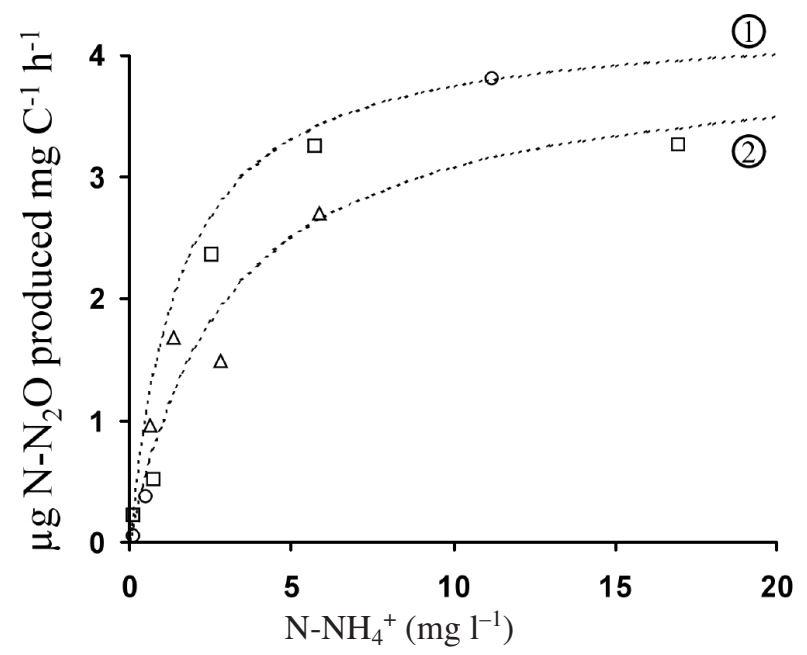

Fig. 6. Nitrous oxide production under oxic stress $\left(\mathrm{O}_{2}=\right.$ $1.25 \mathrm{mg} \mathrm{l}^{-1}$ ) as a function of ammonium concentration in batch culture. Different symbols represent 3 different batch cultures. Two Michaëlis-Menten curves are shown; kinetics parameters are: (1) $V_{\operatorname{maxN}_{2} \mathrm{O}}=4.3 \mu \mathrm{g} \mathrm{N}-\mathrm{N}_{2} \mathrm{O}$ produced $\mathrm{mg} \mathrm{C}^{-1}$ $\mathrm{h}^{-1}$ and $K_{\mathrm{NH}_{4}}^{\prime}=1.5 \mathrm{mg} \mathrm{N}-\mathrm{NH}_{4}{ }^{+} \mathrm{l}^{-1}$; (2) $V_{\text {maxN }_{2} \mathrm{O}}=4 \mu \mathrm{g} \mathrm{N}-\mathrm{N}_{2} \mathrm{O}$ produced $\mathrm{mg} \mathrm{C}^{-1} \mathrm{~h}^{-1}$ and $K_{\mathrm{NH}_{4}}^{\prime}=3 \mathrm{mg} \mathrm{N}^{\prime} \mathrm{NH}_{4}{ }^{+} \mathrm{l}^{-1}$ 


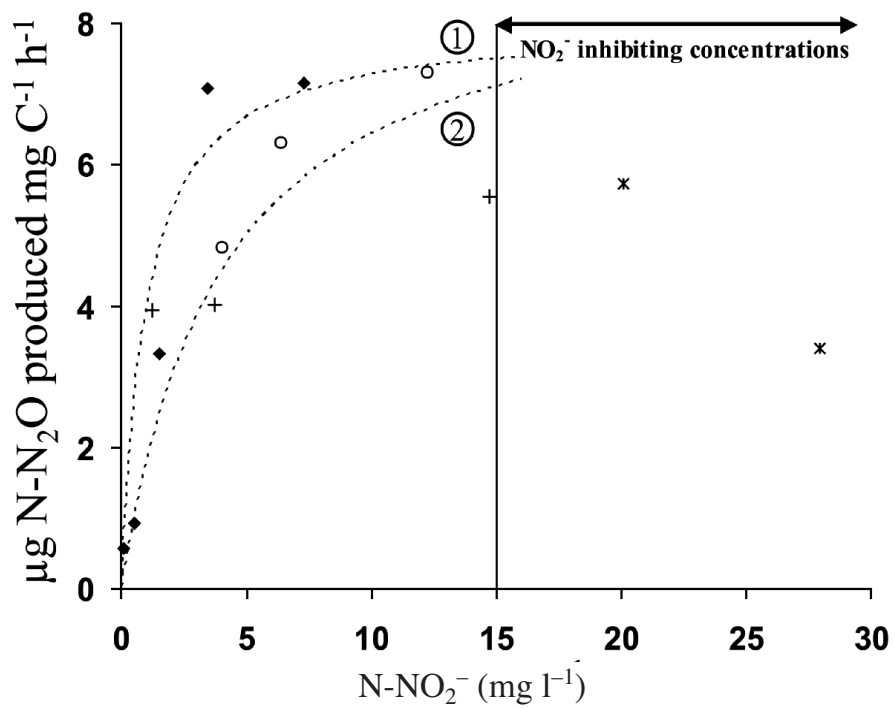

Fig. 7. Nitrous oxide production under oxic stress $\left(\mathrm{O}_{2}=\right.$ $1.25 \mathrm{mg} \mathrm{l}^{-1}$ ) as a function of nitrite concentration in batch culture. Different symbols represent 4 different batch cultures. Two Michaëlis-Menten curves are shown; kinetics parameters are: (1) $V_{\operatorname{maxN_{2}\mathrm {O}}}=8 \mu \mathrm{g} \mathrm{N}-\mathrm{N}_{2} \mathrm{O} \mathrm{mg} \mathrm{C}^{-1} \mathrm{~h}^{-1}$ and $K_{\mathrm{NO}_{2}}^{\prime}=$ $1 \mathrm{mg} \mathrm{N}-\mathrm{NO}_{2}{ }^{-} \mathrm{l}^{-1}$; (2) $V_{\text {maxN }_{2} \mathrm{O}}=9 \mu \mathrm{g} \mathrm{N}-\mathrm{N}_{2} \mathrm{O} \mathrm{mg} \mathrm{C}^{-1} \mathrm{~h}^{-1}$ and $K_{\mathrm{NO}_{2}}^{\prime}=4 \mathrm{mg} \mathrm{N}-\mathrm{NO}_{2}^{-} \mathrm{l}^{-1}$

cific $\mathrm{N}_{2} \mathrm{O}$ production rate reached $7.3 \mu \mathrm{g} \mathrm{N}-\mathrm{N}_{2} \mathrm{O} \mathrm{mg}$ $\mathrm{C}^{-1} \mathrm{~h}^{-1}\left(3.8 \mu \mathrm{g} \mathrm{N}-\mathrm{N}_{2} \mathrm{O} \mathrm{l}^{-1} \mathrm{~h}^{-1}\right)$. At high nitrite concen-

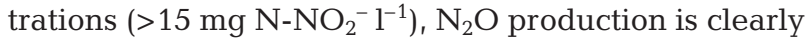
inhibited. Again, observations below this threshold could be fitted on a Michaëlis-Menten curve; $V_{\operatorname{maxN}_{2} \mathrm{O}}$ ranged from 8 to $9 \mu \mathrm{g} \mathrm{N}-\mathrm{N}_{2} \mathrm{O} \mathrm{mg} \mathrm{C} \mathrm{C}^{-1} \mathrm{~h}^{-1}$, and $K_{\mathrm{NO}_{2}}^{\prime}$ ranged from 1 to $4 \mathrm{mg} \mathrm{N}-\mathrm{NO}_{2}^{-} \mathrm{l}^{-1}$ (Fig. 7).

The $V_{\text {maxN }_{2} \mathrm{O}}$ obtained from varying ammonium concentrations (Fig. 6) corresponded exactly to half the value of the maximum specific rate measured at the optimal concentration of both nitrite and ammonium, demonstrating that nitrite concentrations between 3.18 and $4.3 \mathrm{mg} \mathrm{N}-\mathrm{NO}_{2}^{-} \mathrm{l}^{-1}$ were not saturating but around the half-saturation concentration (Fig 7). Interestingly, this maximum specific rate of $\mathrm{N}_{2} \mathrm{O}$ production by AOB ( 8 to $9 \mu \mathrm{g} \mathrm{N}-\mathrm{N}_{2} \mathrm{O} \mathrm{mg} \mathrm{C}^{-1} \mathrm{~h}^{-1}$ ) is about 100 times lower than the specific rate of ammonium oxidation by AOB under oxic conditions $\left(0.05 \mathrm{mmol} \mathrm{N} \mathrm{mg} \mathrm{C}^{-1} \mathrm{~h}^{-1}\right.$, i.e. $700 \mu \mathrm{g} \mathrm{N} \mathrm{mg} \mathrm{C} \mathrm{C}^{-1} \mathrm{~h}^{-1}$ ).

\section{DISCUSSION}

\section{Nitrification process in batch and continuous cultures}

Due to the large ammonium input in secondarily treated wastewater effluent from Paris (Brion \& Billen 2000, Garnier et al. 2001, Cébron et al. 2003), nitrifica- tion is a dominant $\mathrm{N}$-transformation process in the lower Seine river and freshwater estuary.

Molecular analysis by DGGE of the AOB community composition showed that the 2 major AOB present in our batch culture were the same as those that dominated in situ (Cébron et al. 2004), and belonged to Cluster 6a represented by Nitrosomonas oligotropha and $N$. ureaelike bacteria (Fig. 4). These same 2 species also dominated continuous cultures; however, at the end of the experiment, 2 other bacteria (Chem3-b36 and Chem3b39) not previously identified in situ grew in the cultures. On the whole, the nitrifying bacterial community in the (batch or chemostat) cultures can be considered representative of that in situ. The low diversity observed in these culture experiments was probably due to dominance by a small number of species that formed the strongest band on DGGE; rarer species formed weak bands that were hardly discernable. Regardless, this low diversity was in agreement with diversity observed in situ in the Seine river, with dominance by the same species. The non-nitrifying species (Band Chem3-b40-D, see Cébron et al. 2004) was detected as a miss-target of the PCR primer set; it subsequently disappeared, indicating selection for a true nitrifying community.

Bacterial cultures always began with a lag phase, followed by rapid ammonium consumption within about $50 \mathrm{~h}$. Observed rates of ammonium oxidation (0.6 to $0.8 \mathrm{mg} \mathrm{N}-\mathrm{NH}_{4}{ }^{+} \mathrm{l}^{-1} \mathrm{~h}^{-1}$ ) were much higher than potential nitrifying activities measured for in situ communities (Brion \& Billen 2000, Cébron et al. 2003). According to Féray (2000), the specific activities of AOB of the genus Nitrosomonas would range between 0.9 and $5 \mathrm{fmol} \mathrm{NO}_{2}^{-} \mathrm{cell}^{-1} \mathrm{~h}^{-1}\left(12.6\right.$ to $70 \times 10^{-12} \mathrm{mg} \mathrm{N}$ $\mathrm{NO}_{2}^{-}$cell ${ }^{-1} \mathrm{~h}^{-1}$, losses of $\mathrm{N}-\mathrm{N}_{2} \mathrm{O}$ being negligible); therefore, the ammonia oxidizing activities found in our batch cultures would be supported by a bacterial community of 1 to $6.10^{10}$ cells $1^{-1}$. Using the classical carbon content of $20 \mathrm{fg} \mathrm{C} \mathrm{cell}^{-1}$, the estimates of nitrifying bacterial biomass converge to a value of 0.2 to $1 \mathrm{mg} \mathrm{C}^{-1}$ in both batch and continuous cultures; these estimates are in good agreement with values determined by modeling bacterial growth in the cultures (Table 1, Fig 3). Note that we measured around 0.7 to $2 \times 10^{8}$ AOB cells $~^{-1}$ in the maximum nitrifying bacterial concentration in the upper Seine river estuary (Cebron et al. 2003, 2004), i.e. 50 to 1000 times less than in our enriched cultures.

\section{$\mathrm{N}_{2} \mathrm{O}$ production by nitrifer-denitrification}

Lack of denitrification activity in the continuous culture under aerobic conditions (equilibrated mass balance of nitrogen in the culture, i.e. ammonia consumption equal to the nitrate production), in inhibition tests, 
and at stable $\mathrm{NO}_{3}{ }^{-}$concentration during oxic stresses all indicate $\mathrm{N}_{2} \mathrm{O}$ production by nitrifier-denitrification. The cessation of $\mathrm{N}_{2} \mathrm{O}$ production with the addition of the nitrification inhibitor allylthiourea, specific to nitrification, further confirmed the role of nitrifier-denitrification as a source of $\mathrm{N}_{2} \mathrm{O}$. The effectiveness of other nitrification inhibitors (N-serve $10 \mu \mathrm{g} \mathrm{ml} \mathrm{m}^{-1}$, allylthiourea $100 \mu \mathrm{M}$ and phenylacetylene $5 \mu \mathrm{g} \mathrm{ml}^{-1}$ ), on $\mathrm{NO}$ and $\mathrm{N}_{2} \mathrm{O}$ production from $\mathrm{NO}_{2}^{-}$by Nitrosomonas europaea under reduced oxygen conditions (1 kPa of $\mathrm{O}_{2}$ ) was also reported by Anderson et al. (1993).

\section{Role of oxygen, ammonium and nitrite}

Depending on the ammonia oxidizing species present in the system studied, variable $\mathrm{N}_{2} \mathrm{O}$ production can be observed. For exemple, Jiang \& Bakken (1999) demonstrated that, with a pure culture of mixed Nitrospira strains, the level of $\mathrm{N}_{2} \mathrm{O}$ production increased gradually through the first part of the growth period and reached more or less stable levels at 0.2 to $0.3 \%$ of ammonia oxidation rates. With single species cultures, e.g. Nitrosomonas europaea and Nitrosospira multiformis, the proportion was higher than $0.5 \%$. We achieved one of our goals - to define the optimal conditions of $\mathrm{N}_{2} \mathrm{O}$ production by natural Seine river freshwater $\mathrm{AOB}$, and quantify $\mathrm{N}_{2} \mathrm{O}$ production levels in such natural mixed communities - which has been previously accomplished for only a few pure culture species.

\section{Oxygen}

According to Diab et al. (1993), oxygen limitation leads to physiological modifications in nitrifying bacteria. The enzyme systems of Nitrosomonas quickly adapt to changing redox conditions. These physiological adaptations can explain the induction of $\mathrm{N}_{2} \mathrm{O}$ production that we observed after $3 \mathrm{~h}$ in oxic stress only. In addition, aerobic nitrifiers have been reported to be able to switch from a nitrifying to denitrifying activity under conditions of oxygen stress, with molecular hydrogen, hydroxylamine or organic matter (pyruvate, formate) as electron donors, producing $\mathrm{NO}, \mathrm{N}_{2} \mathrm{O}$ and $\mathrm{N}_{2}$ (Ritchie \& Nicholas 1972, Abeliovich \& Vonshak 1992, Bock et al. 1995). Further, nitrification in sediment can remain quite high $(>77 \%$ of the aerobic activity) after $12 \mathrm{~d}$ under oxygen-limited conditions $\left(<0.1 \mathrm{mg} \mathrm{O}_{2} \mathrm{l}^{-1}\right.$ ) (Philips et al. 2002), a finding that confirms that nitrifying bacteria possess an alternative metabolism in low oxygen pressure environment. To our knowledge, while $\mathrm{N}_{2} \mathrm{O}$ production by ammonia oxidizers at low dissolved oxygen concentrations has already been reported for both pure cultures and populations obtained from natural environments, an exploration of $\mathrm{N}_{2} \mathrm{O}$ production between 0.25 and $7.5 \mathrm{mg} \mathrm{O}_{2} \mathrm{l}^{-1}$, with short intervals of oxygen concentration in the lower range, has never before been examined for a mixed culture of natural freshwater nitrifying communities.

The peak in $\mathrm{N}_{2} \mathrm{O}$ emission determined for low dissolved oxygen concentrations (between 1.1 and $1.25 \mathrm{mg} \mathrm{O}_{2} \mathrm{l}^{-1}$ ) cannot be compared to other studies, because it is not usually clear whether $\mathrm{N}_{2} \mathrm{O}$ was produced by nitrification, denitrification or other mechanisms, e.g. anammox. After testing 3 dissolved oxygen concentrations $\left(0.5,1.5,2.5 \mathrm{mg} \mathrm{l}^{-1}\right)$, Jianlong \& Ning (2004) determined that optimal conditions for incomplete nitrification to nitrite in an experimental wastewater reactor were: $\mathrm{pH}=7.5$, dissolved oxygen $=1.5 \mathrm{mg} \mathrm{O}_{2} \mathrm{l}^{-1}$, and $T=30^{\circ} \mathrm{C}$. Although they did not measure $\mathrm{N}_{2} \mathrm{O}$ production, our results agreed well with theirs if we assume that $\mathrm{N}_{2} \mathrm{O}$ was produced under the same conditions as those leading to incomplete nitrification.

Similarly, in lake sediments, ammonia oxidized to nitrite was further transformed into $\mathrm{N}_{2} \mathrm{O}$ by nitrifierdenitrification at 0.2 to $1.0 \mathrm{mg} \mathrm{O}_{2} \mathrm{l}^{-1}$ (Downes 1988). Further, as nitrite and oxygen compete for electron removal during nitrification, this mechanism can explain the finding by Anderson et al. (1993) that optimum $\mathrm{N}_{2} \mathrm{O}$ production by Nitrosomonas europaea occurs at a partial oxygen pressure of $0.4 \mathrm{kPa}(2 \%$ air saturation equivalent to $1.68 \mathrm{mg} \mathrm{O}_{2} \mathrm{l}^{-1}$ ), but that this oxygen effect disappears when nitrite concentrations exceed $0.5 \mathrm{mM}$ (nitrite addition). This is consistent with our conclusion regarding the double role of both oxygen and nitrite in $\mathrm{N}_{2} \mathrm{O}$ production. Finally, the work of Burgess et al. (2002), which showed that $\mathrm{N}_{2} \mathrm{O}$ production by mixed cultures occurred at oxygen concentrations between 1 and $4 \mathrm{mg} \mathrm{l}^{-1}$ with a higher production at $1 \mathrm{mg} \mathrm{l}^{-1}$, further supports our results.

It is worth noting that according to a number of authors, $\mathrm{N}_{2} \mathrm{O}$ is not the major gas produced by nitrifierdenitrification. Kuai \& Verstraete (1998) stated that $\mathrm{N}_{2}$ was the dominant product $(80 \%)$ of the OLAND (Oxygen Limited Autotrophic Nitrification Denitrification) process, while $\mathrm{N}_{2} \mathrm{O}$ represented around $20 \%$ of total $\mathrm{N}$ removed in their batch cultures when dissolved oxygen varied between 0.1 and $0.8 \mathrm{mg} \mathrm{O}_{2} \mathrm{l}^{-1}$. This proportion was much higher than ours; we observed about 1 to $2 \%$ of $\mathrm{N}_{2} \mathrm{O}$ production with respect to ammonia oxidation, which was closer to the values reported by Kester et al. (1997). These authors incubated Nitrosomonas europaea at different oxygen saturations and found that about 0.9 and $0.15 \%$ of ammonium was converted into $\mathrm{NO}$ and $\mathrm{N}_{2} \mathrm{O}$, respectively, at $80 \%$ oxygen saturation (i.e. $6.72 \mathrm{mg} \mathrm{O}_{2} \mathrm{l}^{-1}$ ), and 2.3 and $0.8 \%$ at $1 \%$ saturation (i.e. $0.84 \mathrm{mg} \mathrm{O}_{2} \mathrm{l}^{-1}$ ). 


\section{Ammonium}

In the environment, particularly in soil, $\mathrm{N}_{2} \mathrm{O}$ is produced by both nitrifier-denitrification and heterotrophic denitrification. Avrahami et al. (2002) estimated that the nitrification contribution to total $\mathrm{N}_{2} \mathrm{O}$ release increased from $25 \%$ at low ammonia concentrations (6.5 $\mathrm{\mu g} \mathrm{N}-\mathrm{NH}_{4}{ }^{+} \mathrm{g}^{-1}$ dry weight soil) to $52 \%$ at high ammonia concentrations (395 $\mu \mathrm{g} \quad \mathrm{N}_{-} \mathrm{NH}_{4}{ }^{+} \mathrm{g}^{-1}$ dry weight soil). Similar to the hyperbolic representation found here for $\mathrm{N}_{2} \mathrm{O}$ produced as a function of variable ammonium concentrations (for non-limiting nitrite concentration and $1.25 \mathrm{O}_{2} \mathrm{l}^{-1}$ ), Burgess et al. (2002) showed that, for activated sludge (0.48 to $3.3 \mathrm{mg} \mathrm{N}$ $\mathrm{NH}_{3} \mathrm{~g}^{-1} \mathrm{SPM}, 4.9 \pm 0.3 \mathrm{mg} \mathrm{O} \mathrm{l}^{-1}$ and $\mathrm{pH}$ of $7.2-7.5$ ), $\mathrm{N}_{2} \mathrm{O}$ production increased with ammonium concentration and became saturated when ammonium concentration was greater than $1.6 \mathrm{mg} \mathrm{N}-\mathrm{NH}_{3} \mathrm{~g}^{-1} \mathrm{SPM}$.

In the range of tested ammonium concentrations $(0.08$ to $\left.16.9 \mathrm{mg} \mathrm{N}-\mathrm{NH}_{4}{ }^{+} \mathrm{l}^{-1}\right), V_{\mathrm{N}_{2} \mathrm{Omax}}$ values of 4.0 to $4.3 \mu \mathrm{g} \mathrm{N}$ $\mathrm{N}_{2} \mathrm{O} \mathrm{mg} \mathrm{C}^{-1} \mathrm{~h}^{-1}$ would in fact reach 8 to $9 \mu \mathrm{gN}-\mathrm{N}_{2} \mathrm{O}$ $\mathrm{mg} \mathrm{C}^{-1} \mathrm{~h}^{-1}$ as nitrite was added to a concentration near the $K_{\mathrm{N}_{2} \mathrm{O}}^{\prime} \mathrm{N}_{2} \mathrm{O}$ production would therefore represent 1 to $2 \%$ of the specific ammonium oxidation rate at saturating oxygen concentration. We did not observe any inhibition within the tested range; however, high concentrations of free ammonia and free nitrous acid can impede the activity and growth of nitrifying bacteria (Anthonisen et al. 1993, Hwang \& Hanaki 2000). Whereas specific activities ( $V_{\text {maxNH }_{4}}$ and $V_{\text {maxN }_{2} \mathrm{O}}$ ) differ by a factor of 100, the corresponding half saturation constant $\left(K_{\mathrm{NH}_{4}}\right.$ and $K^{\prime}{ }_{\mathrm{NH}_{4}}$ ) are closer for both oxidation pathways of the AOB (nitrification and nitrifer denitrification).

\section{Nitrite}

In environmental studies, nitrite is often ignored because its concentration is very low in most field conditions (soils, freshwater, marine environments) (Meybeck 1982). In most studies, nitrite is grouped with nitrate and reported as a combination of $\mathrm{NO}_{3}^{-}$and $\mathrm{NO}_{2}{ }^{-}$. Furthermore, most studies disregard nitrite as a possible controller of $\mathrm{N}$ trace gas emissions ( $\mathrm{NO}$ and $\mathrm{N}_{2} \mathrm{O}$ ), except those by Anderson et al. (1993) and Kester et al. (1997), who demonstrated that after decreasing aeration, Nitrosomonas europaea emitted large shortlasting peaks of $\mathrm{NO}$ and $\mathrm{N}_{2} \mathrm{O}$ in the presence of nitrite, but not in its absence. Discarding the inhibition phase for nitrite concentrations $>15 \mathrm{mg} \mathrm{N}-\mathrm{NO}_{2}{ }^{-} \mathrm{l}^{-1}$, the hyperbolic curve showed that the maximum $\mathrm{N}_{2} \mathrm{O}$ production rate $\left(V_{\operatorname{maxN}_{2} \mathrm{O}}\right.$ ) varied between 8 and $9 \mu \mathrm{g} \mathrm{N}-\mathrm{N}_{2} \mathrm{O}$ mg $\mathrm{C}^{-1}$ $\mathrm{h}^{-1}$, exactly as one would expect above at optimal nitrite concentrations. In summary, $\mathrm{N}_{2} \mathrm{O}$ production by AOB accounted for 1 to $2 \%$ of their specific activity at low oxygen concentration, with $K^{\prime}{ }_{\mathrm{NO}_{2}}$ values ranging from 1 to $4 \mathrm{mg} \mathrm{N}-\mathrm{NO}_{2}{ }^{-} \mathrm{l}^{-1}$, thus demonstrating a wide range of affinity for the substrate.

\section{CONCLUSIONS}

We have provided kinetics formulations and parameters values for the 3 stages of the nitrification process: the 2 known stages of aerobic nitrification (i.e. ammonia oxidation and nitrite oxidation; Brion \& Billen 1998, this study) and for nitrifier-denitrification (this study). In addition, for ammonium and nitrite oxidations under oxic conditions, our simulation of batch and continuous cultures with natural communities of nitrifying bacteria confirmed the range of parameters compiled and determined by Brion \& Billen (1998) for pure cultures of AOB and NOB (Table 3).

Regarding the nitrifier-denitrification at the origin of $\mathrm{N}_{2} \mathrm{O}$ production from ammonia and nitrite consumption, the kinetics and parameter values of $\mathrm{N}_{2} \mathrm{O}$ production were fully described for the first time (i.e. half-saturation constant of 1.5 to $3 \mathrm{mg} \mathrm{N} \mathrm{l}^{-1}$ for ammonium, and 1 to $4 \mathrm{mg}$ $\mathrm{N}^{-1}$ for nitrite; a specific rate of $\mathrm{N}_{2} \mathrm{O}$ production $V_{\max N_{2} \mathrm{O}}$ of 8 to $9 \mu \mathrm{g} \mathrm{N}-\mathrm{N}_{2} \mathrm{O}$ produced $\mathrm{mg} \mathrm{C}^{-1} \mathrm{~h}^{-1}$ ).

Our study opens the way for future modeling of the processes of nitrification and nitrifier-denitrification in natural environments. In order to simulate $\mathrm{N}_{2} \mathrm{O}$ emission from the Seine river, a next step will be to incorporate the description of these processes into the RIVERSTRAHLER model to simulate $\mathrm{N}_{2} \mathrm{O}$ emission. This model, which describes the ecological functioning of the Seine river, already includes most microbial processes like algal growth, heterotrophic bacterial activity, and denitrification, etc. (Billen \& Servais 1989, Lancelot et al. 1991, Billen et al. 1994, 1999, Garnier et al. 1995, Brion \& Billen 2000). Once validated, the model will be used to explore impacts of management measures, like that of tertiary treatment of urban effluents on the nitrification and $\mathrm{N}_{2} \mathrm{O}$ production in the lower Seine river. More generally, the formulation of the process of $\mathrm{N}_{2} \mathrm{O}$ emission could also be applied to other models, i.e. on a global scale where $\mathrm{N}_{2} \mathrm{O}$ emission is often represented by simple statistical relationships (Setzinger \& Kroeze 1998, Bouwman et al. 2002), which will further increase our understanding of the nitrogen cycle in aquatic environments and improve our quantification of $\mathrm{N}_{2} \mathrm{O}$ emissions.

Acknowledgements. This work was undertaken within the framework of the PIREN-Seine programme (initiated by the CNRS) and the Seine-Aval programme (supported by the Région Haute-Normandie). We are indebted to A. Ficht from the SNS (Service de Navigation de la Seine) for his kind help in the field. We thank A. Martinez for technical assistance and H. J. Laanbroek for hosting us in his laboratory for DGGE analysis. 


\section{LITERATURE CITED}

Abeliovich A, Vonshak A (1992) Anaerobic metabolism of Nitrosomonas europaea. Arch Microbiol 158:267-270

Anderson IC, Poth M, Homstead J, Burdige D (1993) A comparison of $\mathrm{NO}$ and $\mathrm{N}_{2} \mathrm{O}$ production by the autotrophic nitrifier Nitrosomonas europaea and the heterotrophic nitrifier Alcaligenes faecalis. Appl Environ Microbiol 59: 3525-3533

Anthonisen AC, Loehr RC, Prakasam TBS, Srinath EG (1993) Inhibition of nitrification by ammonia and nitrous acid. J Water Pollut Control Fed 48:835-852

Avrahami S, Conrad R, Braker G (2002) Effect of soil ammonium concentration on $\mathrm{N}_{2} \mathrm{O}$ release and on the community structure of ammonia oxidizers and denitrifiers. Appl Environ Microbiol 68:5685-5692

Billen G, Servais P (1989) Modélisation des processus de dégradation bactérienne de la matière organique en milieu aquatique. In: Bianchi M, Marty D, Bertrand JC, Caumette P, Gauthier M (eds) Micro-organismes dans les écosystèmes océaniques. Masson, Paris, p 219-245

Billen G, Garnier J, Hanset P (1994) Modelling phytoplankton development in whole drainage networks: the RIVERSTRAHLER Model applied to the Seine river system. Hydrobiologia 289:119-137

Billen G, Garnier J, Deligne C, Billen C (1999) Estimates of early-industrial inputs of nutrients to river systems: implication for coastal eutrophication. Sci Total Environ 243-244:43-52

Bock E, Schmidt I, Stüven R, Zart D (1995) Nitrogen loss caused by denitrifying Nitrosomonas cells using ammonium or hydrogen as electron donors and nitrite as electron acceptor. Arch Microbiol 163:16-20

Bonin P, Tamburini C, Michotey V (2002) Determination of the bacterial processes which are sources of nitrous oxide production in marine samples. Water Res 36:722-732

Bouwman AF, Boumans LJM, Batjes NH (2002) Modeling global and annual $\mathrm{N}_{2} \mathrm{O}$ and $\mathrm{NO}$ emissions from fertilized fields. Global Biogeochem Cycles 16(4):28-1-28-8

Brion N, Billen G (1998) Une réévaluation de la méthode d'incorporation de $\mathrm{H}_{14} \mathrm{CO}_{3}{ }^{-}$pour mesurer la nitrification autotrophe et son application pour estimer des biomasses de bactéries nitrifiantes. Rev Sci Eau 11:283-302

Brion N, Billen G (2000) Wastewater as a source of nitrifying bacteria in river systems: the case of the river Seine downstream from Paris. Water Res 34:3213-3221

Brion N, Billen G, Guezennec L, Ficht A (2000) Distribution of nitrifying activity in the Seine River (France) from Paris to the estuary. Estuaries 23:669-682

Burgess JE, Colliver BB, Stuetz RM, Stephenson T (2002) Dinitrogen oxide production by a mixed culture of nitrifying bacteria during ammonia shock loading and aeration failure. J Ind Microbiol Biotechnol 29:309-313

Cébron A, Berthe T, Garnier J (2003) Nitrification and nitrifying bacteria in the lower Seine river and estuary (France). Appl Environ Microbiol 69:7091-7100

Cébron A, Coci M, Garnier J, Laanbroek HJ (2004) DGGE analysis of the ammonia oxidizing bacterial community structure in the lower Seine River: impact of the Paris wastewater effluents. Appl Environ Microbiol 70:6726-6737

Crutzen PJ (1981) Atmospheric chemical processes of the oxides of nitrogen, including nitrous oxide. In: Delwiche CC (ed) Denitrification, nitrification and nitrous oxide. Wiley \& Sons, New York, p 17-44

Diab S, Kochba M, Avnimelech Y (1993) Nitrification pattern in a fluctuating anaerobic-aerobic pond environment. Water Res 27:1469-1475
Dong LF, Nedwell DB, Underwood GJC, Thornton DCO, Rusmana I (2002) Nitrous oxide formation in the Colne Estuary, England: the central role of nitrite. Appl Environ Microbiol 68:1240-1249

Downes MT (1988) Aquatic nitrogen transformations at low oxygen concentrations. Appl Environ Microbiol 54: $172-175$

Féray C (2000) Nitrification en sédiment d'eau douce: incidence de rejets de station d'épuration sur la dynamique de communautés nitrifiantes. PhD thesis, University of Lyon I

Garnier J, Billen G, Coste M (1995) Seasonal succession of diatoms and Chlorophyceae in the drainage network of the Seine River: observations and modelling. Limnol Oceanogr 40:750-765

Garnier J, Servais P, Billen G, Akopian M, Brion N (2001) Lower Seine river and estuary (France) carbon and oxygen budgets during low flow. Estuaries 24:964-976

Garnier J, Cébron A, Tallec G, Billen G, Sébilo M, Martinez A (in press) Nitrous oxide emission in the Seine River estuary (France): comparison with upstream sector of the Seine basin. Biogeochemistry

Houghton JT, Meira Filho LG, Callander BA, Harris N, Kattenberg A, Maskell K (eds) (1996) Climate change 1995: the science of climate change. Cambridge University Press, Cambridge

Hutchinson GL, Guenzi WD, Livingston GP (1993) Soil water controls on aerobic soil emission of gaseous nitrogen oxides. Soil Biol Biochem 25:1-9

Hwang S, Hanaki K (2000) Effects of oxygen concentration and moisture content of refuse on nitrification, denitrification and nitrous oxide production. Bioresour Technol 71: 159-165

Jiang QQ, Bakken LR (1999) Nitrous oxide production and methane oxidation by different ammonia-oxidizing bacteria. Appl Environ Microbiol 65:2679-2684

Jianlong W, Ning Y (2004) Partial nitrification under limited dissolved oxygen conditions. Process Biochem 39:1223-1229

Kester RA, De Boer W, Laanbroek HJ (1997) Production of NO and $\mathrm{N}_{2} \mathrm{O}$ by pure cultures of nitrifying and denitrifying bacteria during changes in aeration. Appl Environ Microbiol 63:3872-3877

Kowalchuk GA, Bodelier PLE, Hans G, Heilig J, Stephen JR, Laanbroek HJ (1998) Community analysis of ammoniaoxidizing bacteria, in relation to oxygen availability in soils and root-oxygenated sediments, using PCR, DGGE and oligonucleotide probe hybridization. FEMS Microbiol Ecol 27:339-350

Kuai L, Verstraete W (1998) Ammonium removal by the oxygen-limited autotrophic nitrification-denitrification system. Appl Environ Microbiol 64:4500-4506

Lancelot C, Billen G, Veth C, Becquevort S, Mathot S (1991) Modelling carbon cycling through phytoplankton and microbes in the Scotia-Weddell Sea area during sea ice retreat. Mar Chem 35:305-324

Meybeck M (1982) Carbon, nitrogen and phosphorus transport by world rivers. Am J Sci 282:450

Muller EB, Stouthamer AH, Van Verseveld HW (1995) Simultaneous $\mathrm{NH}_{3}$ oxidation and $\mathrm{N}_{2}$ production at reduced $\mathrm{O}_{2}$ tensions by sewage sludge subcultured with chemolithotrophic medium. Biodegradation 6:339-349

Muyzer G, de Waal EC, Uitterlinden AG (1993) Profiling of complex microbial populations by denaturing gradient gel electrophoresis analysis of polymerase chain reactionamplified genes coding for 16S rRNA. Appl Environ Microbiol 59:695-700

Philips S, Wyffels S, Spengers R, Verstraete W (2002) Oxygenlimited autotrophic nitrification/denitrification by ammo- 
nia oxidisers enables upward motion towards more favourable conditions. Appl Microbiol Biotechnol 59: 557-566

Poth M, Focht DD (1985) $\mathrm{N}^{-15}$ kinetic analysis of $\mathrm{N}_{2} \mathrm{O}$ production by Nitrosomonas europaea: an examination of nitrifier denitrification. Appl Environ Microbiol 49:1134-1141

Ritchie GA, Nicholas DJ (1972) Identification of the sources of nitrous oxide produced by oxidative and reductive processes in Nitrosomonas europaea. Biochem J 126: $1181-1191$

Rodier J (1984) Substances et critères chimiques indicateurs de pollution. In: Dunod (ed) L'analyse de l'eau (eaux naturelles, eaux résiduaires, eau de mer), 7th edn. Anions, Paris, p 149-230

Sébilo M, Billen G, Mayer B, Billiou D, Grably M, Garnier J, Mariotti A (in press). Assessing nitrification and denitrification in the Seine River and Estuary using chemical and isotopic techniques. Ecosystems

Seitzinger SP, Kroeze C (1998) Global distribution of nitrous

Editorial responsibility: Frede Thingstad,

Bergen, Norway oxide production and $\mathrm{N}$ inputs in freshwater and coastal ecosystems. Global Biochem Cycles 12:93-113

Seitzinger SP, Kroeze C, Styles RV (2000) Global distribution of $\mathrm{N}_{2} \mathrm{O}$ emissions from aquatic systems: natural emissions and anthropogenic effects. Chemosphere Global Change Sci 2:267-279

Slavyck G, McIsaac JJ (1972) Comparison of two automated ammonium methods in a region of coastal upwelling. Deep-Sea Res 19:1-4

Svensson JM, Enrich-Prast A, Leonardson L (2001) Nitrification and denitrification in a eutrophic lake sediment bioturbated by oligochaetes. Aquat Microb Ecol 23:177-186

Wrage N, Velthof GL, Beusichem MLV, Oenema O (2001) Role of nitrifier denitrification in the production of nitrous oxide. Soil Biol Biochem 33:1723-1732

Wrage N, Velthof GL, Oenema O, Laanbroek HJ (2004) Acetylene and oxygen as inhibitors of nitrous oxide production in Nitrosomonas europaea and Nitrosospira briensis: a cautionary tale. FEMS Microbiol Ecol 47:13-18

Submitted: October 18, 2004; Accepted: July 28, 2005

Proofs received from author(s): September 16, 2005 